Marquette University

e-Publications@Marquette

9-13-2018

\title{
DFT-assisted Design and Evaluation of Bifunctional Copper(I) Catalysts for the Direct Intermolecular Addition of Aldehydes and Ketones to Alkynes
}

Jacob D. Porter

Marquette University

Eric Greve

Marquette University

Abdulmohsen Alsafran

Marquette University

Adam R. Benoit

Marquette University

Sergey V. Lindeman

Marquette University, sergey.lindeman@marquette.edu

See next page for additional authors

Follow this and additional works at: https://epublications.marquette.edu/chem_fac

Part of the Chemistry Commons

\section{Recommended Citation}

Porter, Jacob D.; Greve, Eric; Alsafran, Abdulmohsen; Benoit, Adam R.; Lindeman, Sergey V.; and Dockendorff, Chris, "DFT-assisted Design and Evaluation of Bifunctional Copper(I) Catalysts for the Direct Intermolecular Addition of Aldehydes and Ketones to Alkynes" (2018). Chemistry Faculty Research and Publications. 964.

https://epublications.marquette.edu/chem_fac/964 


\section{Authors}

Jacob D. Porter, Eric Greve, Abdulmohsen Alsafran, Adam R. Benoit, Sergey V. Lindeman, and Chris Dockendorff 
Marquette University

e-Publications@Marquette

\section{Chemistry Faculty Research and Publications/College of Arts and Sciences}

This paper is NOT THE PUBLISHED VERSION; but the author's final, peer-reviewed manuscript. The published version may be accessed by following the link in the citation below.

Tetrahedron, Vol. 74, No. 17 (September 13, 2018): 4823-4836. DOI. This article is (C) Elsevier and permission has been granted for this version to appear in e-Publications@Marquette. Elsevier does not grant permission for this article to be further copied/distributed or hosted elsewhere without the express permission from Elsevier.

\section{DFT-assisted Design and Evaluation of Bifunctional Copper(I) Catalysts for the Direct Intermolecular Addition of Aldehydes and Ketones to Alkynes}

Jacob D. Porter

Department of Chemistry, Marquette University, Milwaukee, WI

Eric Greve

Department of Chemistry, Marquette University, Milwaukee, WI Abdulmohsen Alsafran

Department of Chemistry, Marquette University, Milwaukee, WI Adam R. Benoit

Department of Chemistry, Marquette University, Milwaukee, WI Sergey V. Lindeman

Department of Chemistry, Marquette University, Milwaukee, WI Chris Dockendorff

Department of Chemistry, Marquette University, Milwaukee, WI 


\section{Abstract}

Bifunctional catalysts containing discrete metal pi-acid and amine sites were designed and investigated for the direct intermolecular addition of aldehydes and ketones to unactivated alkynes. Copper(I)-based catalystswere prioritized based on intramolecular (Conia-ene type) reactions, and complexes were designed with tridentate ligands and potentially hemilabile heterocyclic spacers. The structures of the designed catalysts were computed using density functional theory (DFT), and the relative energies of putative catalytic intermediates were estimated and used to prioritize catalyst designs. Novel bifunctional precatalysts containing a thiazole spacer were synthesized via a 9-step sequence and combined with transition metals before screening for the direct addition of aldehydes and ketones to several internal and terminal alkynes. Despite the lack of desired intermolecular reactions, DFT calculations of putative catalyst intermediates appears to be a promising strategy for the design and prioritization of bifunctional catalysts for $\mathrm{C} \_\mathrm{C}$ bond formation.

Graphical abstract

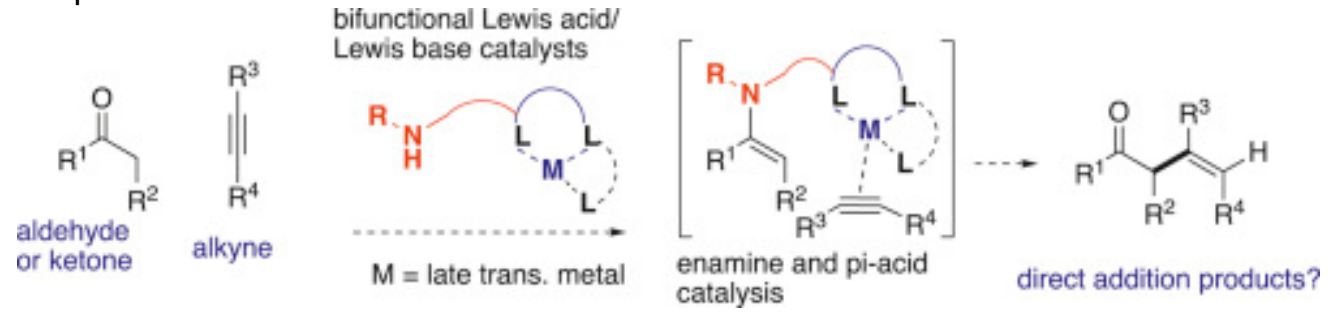

\section{Keywords}

Alkenylation, copper(I), Alkyne activation, Hybrid catalysis, Organocatalysis, Aldehyde, Ketone, Alkyne, DFT, Catalyst design

\section{Introduction}

The controlled formation of carbon-carbon bonds under mild conditions with unactivated substrates continues to be an important focus of modern organic methodology research. The identification of catalysts for such transformations has been facilitated by several enabling technologies that have flourished in recent decades, the most fundamental of which is transition metal complexes that are capable of stabilizing multiple catalytic intermediates. A complementary technology that has exploded since 2000 [1] is the use of organocatalysts for carbon-carbon bond formation [2], most commonly for the activation of aldehydes and ketones with aminebased catalysts. The use of dual organo/transition metal catalysts has further increased the range of transformations available to the organic chemist [[3], [4], [5], [6]], though a natural limitation to this approach is that separate homogeneous catalysts have the potential of poisoning each other. A related strategy is the use of multifunctional (typically bifunctional) catalysts with separate active sites positioned on a single molecule. Amino acids may be the simplest examples of bifunctional catalysts [1]; more complex examples possessing separate Lewis base and transition metal functionality have been reported [7], but have arguably not yet enabled transformations that are impossible with monofunctional or dual catalyst systems. Nonetheless, a number of promising examples have been reported over the years using bifunctional Lewis acid/Lewis base catalysts, including Ito and Hayashi's gold(I)/amino-catalyzed asymmetric isocyanoacetate aldol reaction [8], Shibasaki's aluminum(III)/phosphine oxide catalysts for asymmetric cyanosilylation of aldehydes [9], and Lectka's bifunctional cinchona alkaloid/Lewis acid catalysts for asymmetric $\beta$-lactam synthesis [10].

We hypothesize that rationally designed, bifunctional catalysts, in particular those with carefully positioned Lewis acid/Lewis base pairs, will facilitate specific bond formations not feasible using dual catalyst systems. Our first efforts in this area involved the design of bifunctional organo/transition metal catalysts for direct aldol reactions [11,12], an approach also explored in depth by Mlynarski [[13], [14], [15]] and Wang [[16], [17], [18]]. Expanding upon this approach, we endeavored to design bifunctional catalysts for direct additions of pronucleophiles, such as aldehydes and ketones, to unactivated alkenes and alkynes. Intramoleculardirect additions of aldehydes and ketones to unactivated alkenes and alkynes have been reported; Widenhoefer has 
reported palladium (II) and platinum(II)-catalyzed cyclization of alkene-tethered $\beta$-diketones [19,20], and Coniaene type reactions with alkyne-tethered activated methylenesubstrates have been reported with a variety of transition metals [21]. Conia-ene type reactions with unactivated aldehydes and ketones are challenging, due to unfavorable equilibria with active enol nucleophiles. The use of dual amine catalysts (for aldehyde or ketone activation) and transition metal catalysts (for alkyne activation) for these intramolecular carbocyclizations has been reported by Kirsch [22], Dixon [23], Jørgensen [24], Che [25], and Michelet [[26], [27], [28], [29]].

The respective intermolecular direct addition reactions of aldehydes/ketones to unactivated alkenes/alkynes are rare. Widenhoefer reported the direct addition of stabilized carbon nucleophiles (1,3-dicarbonyl compounds) to ethylene and propylene using $\mathrm{Pd}(\mathrm{II})$ and $\mathrm{Pt}(\mathrm{II})$ catalysts [20]. Nakamura has also reported the metal-catalyzed addition of 1,3-dicarbonyl compounds [30] and stabilized enamines [31] to alkynes using $\operatorname{In}(\text { OTf })_{3}$. Dong has reported simple bifunctional rhodium-based catalysts for the direct addition of ketones to alkenes [32], as well as enamines [33] and ketones [34] to alkynes. More commonly, such transformations are instead performed by preactivating the pronucleophile and/or the electrophileprior to a palladium- or nickel-catalyzed cross-coupling reaction between an enolate anion and an alkenyl halide to generate a $\beta-\gamma$ unsaturated product [35]. MacMillan has also reported a dual copper(II)/amine catalyst system for the coupling of aldehydes with alkenylboronic acids under mild conditions [36].

Though attractive for their mild conditions, we hypothesized that the reported dual catalytic systems for intramolecular carbocyclizations may be unsuitable for intermolecular additions due to the fact that enamine intermediates could outcompete alkyne substrates for coordination to $\pi$-acidic metals. We reasoned that bifunctional catalysts with discrete amine and $\pi$-acidic sites could be designed that could promote net intermolecular reactions between aldehydes/ketones and alkynes via a catalytic intramolecular carbon-carbon bond formation step, with the catalyst itself bringing the reactants together to form favorable macrocyclic intermediates within the putative catalytic cycle (Fig. 1). Herein is described our early efforts towards the design, synthesis, and testing of such bifunctional catalysts for direct additions of aldehydes and ketones to unactivated alkynes.

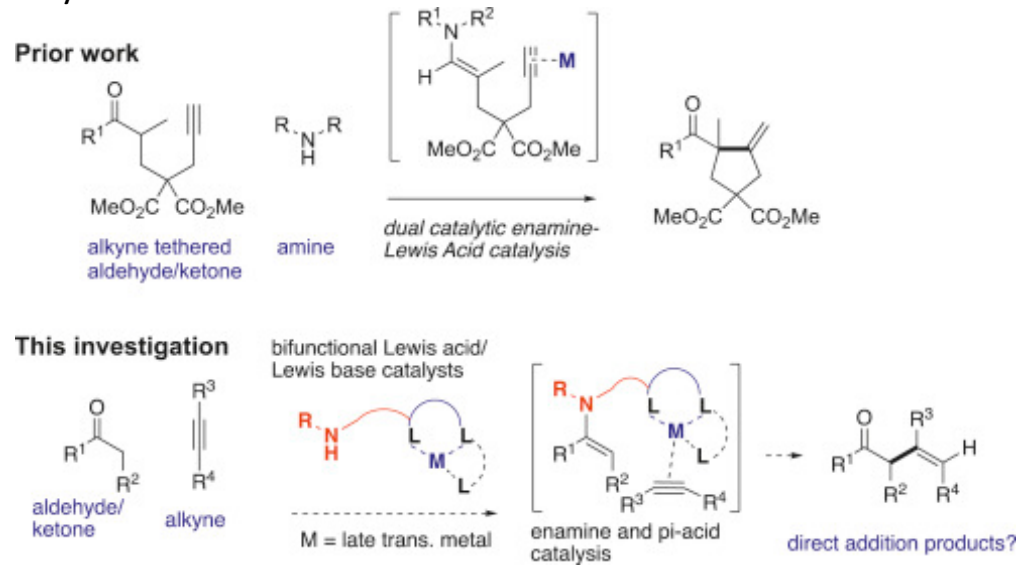

Fig. 1. Dual catalytic intramolecular (Conia-ene type) reaction (top) versus our approach to intermolecular direct additions of aldehydes/ketones to alkynes(bottom).

\section{Results and discussion}

\subsection{Intramolecular (Conia-ene) reaction screening}

In order to determine which metal Lewis acid and ligand combinations could be suitable for incorporation into a bifunctional catalyst, we elected to use an intramolecular reaction as a model. The formyl-alkyne substrate (1a) reported by Michelet [28] was used in a Conia-ene type reaction to screen a variety of metals with precedent for activating alkynes, together with cyclohexylamine as the organocatalyst for 
presumed enaminegeneration (Table 1). The best results were obtained with the group 11 saltscopper (I), silver (I), and gold (I) (entries 1, 3 and 6). With its affordability, functional group tolerance (including protic solvents), good precedent for use in Conia-ene reactions, and its compatibility with a variety of ligand types, we decided to investigate $\mathrm{Cu}(\mathrm{I})$ in greater detail. Consistent with the report from Michelet [28], we discovered that a $\mathrm{Cu}(\mathrm{II})$ source $\left(\mathrm{Cu}(\mathrm{OTf})_{2}\right)$ could be conveniently used (entry 14$)$, which we propose is reduced to an active $\mathrm{Cu}(\mathrm{I})$ species by a fraction of the enamine formed from the substrate and cyclohexylamine. We found that reactions with these $\mathrm{Cu}(\mathrm{II})$ salts tolerated a range of different ligands, including 1,3-propanediol, bipy, pyridine-2-

carboxamide, 2-picolinic acid, PhBOX, and TADDOL. We were enthusiastic about identifying ligand-accelerated reactions [37], however we did not observe any substantial improvement in yield or obvious rate accelerations with different ligands relative to the unligated copper salts, though we can't rule out the possibility that the cyclohexylamine could double as a ligand for copper. The tolerance for various ligands in these $\mathrm{Cu}(\mathrm{I})$-catalyzed reactions nonetheless prompted us to explore several heterocyclic ligand scaffolds that were already in hand for use in bifunctional catalyst systems (vide infra).

Table 1. Intramolecular (Conia-ene) reaction screen.

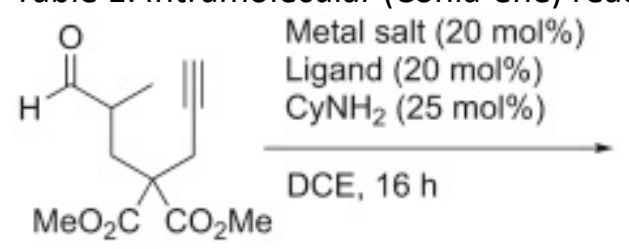

1a

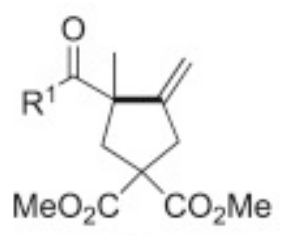

1b

\begin{tabular}{|l|l|l|l|}
\hline Entry & Metal catalyst & Ligand & Yield (\%) \\
\hline 1 & $\left(\mathrm{CH}_{3} \mathrm{CN}\right)_{4} \mathrm{CuBF}_{4}{ }^{\mathrm{b}}$ & - & 37 \\
\hline 2 & $\mathrm{CpCo}(\mathrm{CO})_{2}{ }^{\mathrm{b}}$ & - & - \\
\hline 3 & $\mathrm{PPh}_{3} \mathrm{AuCl} / \mathrm{AgSbF}$ & 34 \\
\hline 4 & $\mathrm{PtCl}_{2} / \mathrm{AgSbF}_{6}$ & - & 17 \\
\hline 5 & $\mathrm{InCl}_{3}$ & - & $<5$ \\
\hline 6 & $\mathrm{AgSbF}_{6}$ & - & 52 \\
\hline 7 & $\mathrm{Zn}(\mathrm{OTf})_{2}$ & - & $<5$ \\
\hline 8 & $\mathrm{NiCl}_{2}$ & - & $<5$ \\
\hline 9 & $\left(\mathrm{CH}_{3} \mathrm{CN}\right)_{4} \mathrm{CuBF}_{4}{ }^{\mathrm{c}}$ & - & 11 \\
\hline 10 & - & - & $<5$ \\
\hline 11 & $\left(\mathrm{CH}_{3} \mathrm{CN}\right)_{4} \mathrm{CuBF}_{4}$ & - & $<5$ \\
\hline 12 & $\left(\mathrm{CH}{ }_{3} \mathrm{CN}\right)_{4} \mathrm{CuBF}_{4}$ & $\mathrm{H}-\mathrm{dpa}$ & 16 \\
\hline 13 & $\left(\mathrm{CH}{ }_{3} \mathrm{CN}\right)_{4} \mathrm{CuBF}_{4}$ & $(R, R)-\mathrm{Ph}-\mathrm{BOX}$ & $<5$ \\
\hline 14 & $\left.\mathrm{Cu}_{4} \mathrm{OTf}\right)_{2}$ & 1,10 phenanthroline & 14 \\
\hline
\end{tabular}

a Formyl alkyne $(0.020 \mathrm{~g}, 0.079 \mathrm{mmol})$ was added to a $1.5 \mathrm{~mL} \mathrm{HPLC}$ vial followed by cyclohexylamine $(1.8 \mu \mathrm{L}$, $0.016 \mathrm{mmol}) .10 \mathrm{~min}$. later, the metal salt $(0.012 \mathrm{mmol})$ was added and reactions stirred for $16 \mathrm{~h}$. Reaction mixtures were filtered through a silica plug, condensed, and yields measured by ${ }^{1} \mathrm{H}$ NMR using pentachloroethane as an internal standard.

${ }^{\mathrm{b}}$ Reagents were mixed in the glove box.

${ }^{\mathrm{c}} \mathrm{Bu}_{4} \mathrm{NCl}(1.0 \mathrm{eq})$ was added.

\subsection{Intermolecular studies related to dual catalysis}

Prior to proceeding with our strategy to build novel bifunctional catalysts, we wanted to rule out the obvious possibility of using the dual catalyst conditions for intermolecular reactions that were productive for intramolecular reactions. We are not aware of any reported successful nor unsuccessful attempts at such intermolecular reactions with unactivated aldehydes/ketones and alkynes using $\mathrm{Cu}(\mathrm{I})$ catalysts. We hypothesized that such reactions could be precluded by the fact that electron-rich enamine intermediates could displace the alkynes and simply act as competing ligands for the $\pi$-acid. To test this hypothesis, we performed several NMR 
studies (Fig. 2). A downfield shift in the ${ }^{1} \mathrm{H}$ NMR signal of the alkyne proton of phenylacetylene was observed upon its addition to (2,2'-dipyridylamine)CuOTf, from $3.07 \mathrm{ppm}$ to $4.01 \mathrm{ppm}$ in $\mathrm{CDCl}_{3}$ (Fig. 2). This is consistent with formation of $\mathrm{Cu}$-alkyne complex 2; an x-ray crystal structure of the related $\mathrm{CuBF}_{4}$ complex was obtained (Fig. 3, left). Upon addition of the enamine derived from cyclohexanone and pyrrolidine, the signal for the uncoordinated alkyne appeared at $3.07 \mathrm{ppm}$. Evidence for enamine coordination to the metal was observed as the vinyl enamine proton moves upfield from $4.29 \mathrm{ppm}$ to $3.99 \mathrm{ppm}$. This chemical shift is observed with or without the presence of the alkyne, suggesting that coordination of the enamine to the metal is highly favored over alkyne coordination. The formation of 1,2-addition product 3 was subsequently observed, which presumably forms via addition of a Cu-acetylide to a transient iminium ion. Variations of this transformation, in the form of 3-component reactions (ketone, amine, and alkyne), were recently reported by Larsen [38] and Ma [39]. We also attempted stoichiometric reactions with putative internal alkyne complexes, which yielded no detectable products.

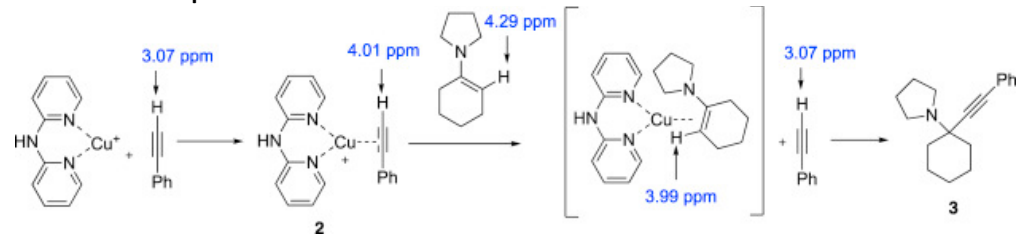

Fig. 2. Enamine displacement of alkyne from (2,2'-dipyridylamine) $\mathrm{Cu}(\mathrm{I})$ complex and 1,2 addition to enamine/iminium ion.

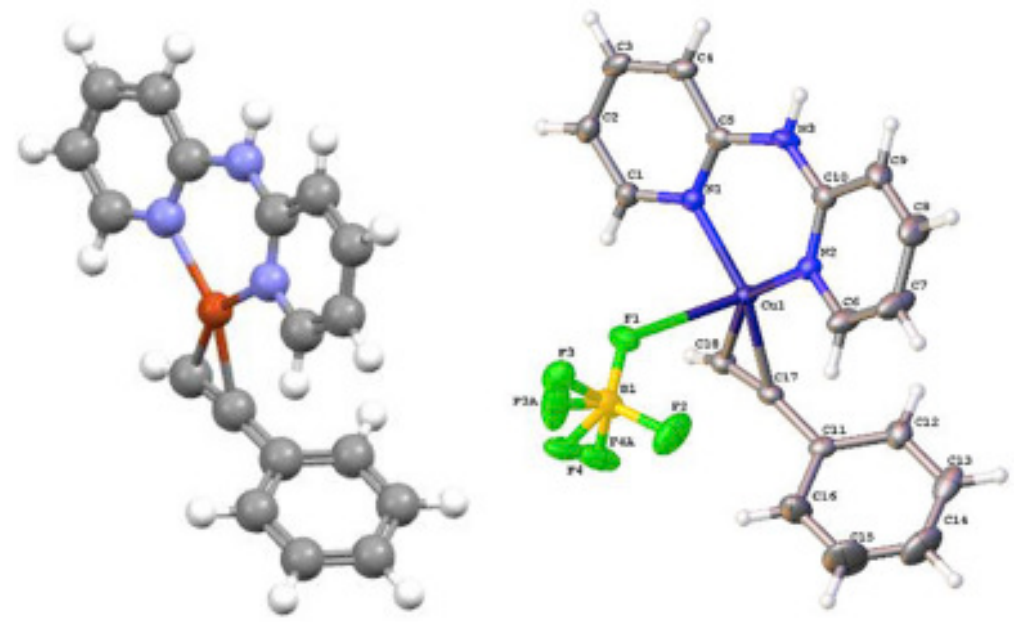

Fig. 3. X-ray structure of (2,2'-dipyridylamine) $\mathrm{Cu}(\mathrm{I})$ complex with phenylacetylene (left); analogous DFToptimized structure (right).

\subsection{Design of bifunctional catalysts and evaluation with density functional theory (DFT) calculations}

The challenge of using $\mathrm{Cu}(\mathrm{I})$ to promote intermolecular reactions with alkynes as electrophiles prompted us to start investigating the hypothesis that pseudo-intramolecular reactions promoted by a bifunctional catalyst could be productive. We elected to prioritize our ideas for novel catalysts with input from DFT geometry optimizations and energy calculations. To evaluate the feasibility of such calculations with $\mathrm{Cu}(\mathrm{I})$ complexes, we calculated the structure of the cationic version of (2,2'-dipyridylamine) $\mathrm{Cu}(\mathrm{I})$ using the functional B3PW91 [40], with the LANL2DZ [41] basis set for $\mathrm{Cu}$, and cc-pVDZ [42] for all other atoms. The resulting minimized structure (Fig. 3, right) was in excellent agreement with the x-ray structure (Fig. 3, left), with both structures showing copper with a distorted tetrahedral coordination geometry, neglecting the $\mathrm{BF}_{4}$ anion in the crystal structure.

Using this DFT method, we computed structures and energies of putative alkyne complexes, as well as the organocopper adducts obtained after the desired intramolecular $\mathrm{C} \_\mathrm{C}$ bond formation between the enamine and the alkyne. We reasoned that unfavorable energetics for this step in a catalytic cycle would make the 
desired reaction unlikely, and promising catalysts will be reasonably exergonic for this step, which is depicted at the top of Table 2. The decrease in enthalpy for addition to the alkyne should outweigh the entropic costs of bringing the reacting partners together, which leads to the formation of a more constrained macrocycle. An advantage to our strategy is that the constrained approach of the enamine to the alkyne will facilitate future transition state calculations; we should emphasize that our present efforts utilize only ground state calculations of postulated catalytic intermediates.

Table 2. DFT calculations for bifunctional catalysis of $\mathrm{C} \_\mathrm{C}$ bond formation with acetone and acetylene ${ }^{\mathrm{a}}$.

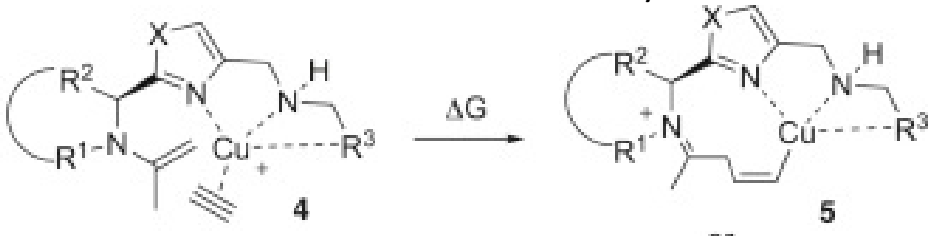
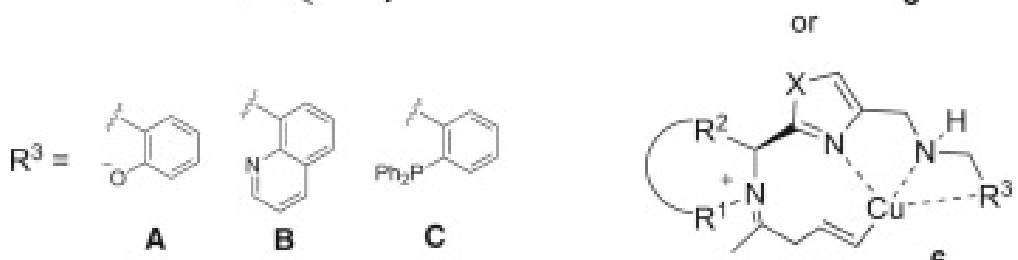

\begin{tabular}{|c|c|c|c|c|c|c|}
\hline Entry & $\mathbf{R}[1]$ & $\mathbf{R}[2]$ & $x$ & $\mathbf{R}[3]$ & cis/trans & $\Delta \mathrm{G}(\mathrm{kcal} / \mathrm{mol})$ \\
\hline 1 & $\mathrm{Me}$ & $\mathrm{H}$ & $\mathrm{NH}$ & A & cis & -0.3 \\
\hline 2 & $\mathrm{Me}$ & $\mathrm{H}$ & $\mathrm{NH}$ & A & trans & +1.1 \\
\hline 3 & $\mathrm{Me}$ & $\mathrm{H}$ & 0 & A & cis & -1.2 \\
\hline 4 & $\mathrm{Me}$ & $\mathrm{H}$ & 0 & A & trans & +10.3 \\
\hline 5 & $\mathrm{Me}$ & $\mathrm{H}$ & $S$ & A & cis & -2.9 \\
\hline 6 & $\mathrm{Me}$ & $\mathrm{H}$ & $\mathrm{S}$ & $A$ & trans & -0.04 \\
\hline 7 & $-\left(\mathrm{CH}_{2}\right)_{3-}$ & & $\mathrm{S}$ & A & cis & -2.1 \\
\hline 8 & $-\left(\mathrm{CH}_{2}\right)_{3-}^{-}$ & & $\mathrm{S}$ & A & trans & +11.0 \\
\hline 9 & $\mathrm{Bn}$ & $\mathrm{H}$ & $\mathrm{S}$ & A & cis & -3.8 \\
\hline 10 & $\mathrm{Bn}$ & $\mathrm{H}$ & $\mathrm{S}$ & A & trans & +3.6 \\
\hline 11 & $\mathrm{Bn}$ & $\mathrm{H}$ & $\mathrm{S}$ & $B$ & cis & -10.2 \\
\hline 12 & $\mathrm{Bn}$ & $\mathrm{H}$ & $\mathrm{S}$ & $\mathrm{B}$ & trans & +6.4 \\
\hline 13 & $-\left(\mathrm{CH}_{2}\right)_{3-}^{-}$ & & $\mathrm{S}$ & $B$ & cis & -5.5 \\
\hline 14 & $-\left(\mathrm{CH}_{2}\right)_{3}-$ & & $\mathrm{S}$ & $B$ & trans & +1.6 \\
\hline 15 & $\mathrm{Me}$ & $\mathrm{H}$ & $\mathrm{S}$ & $\mathrm{C}$ & cis & -10.3 \\
\hline 16 & $\mathrm{Me}$ & $\mathrm{H}$ & $\mathrm{S}$ & C & trans & -4.1 \\
\hline $17^{b}$ & $\mathrm{Bn}$ & $\mathrm{H}$ & $\mathrm{S}$ & B & cis & -17.1 \\
\hline
\end{tabular}

${ }^{a}$ All calculations used functional B3PW91, basis set LANL2DZ for copper, and basis set cc-pVDZ for all other atoms, using DCM as solvent.

${ }^{\mathrm{b}}$ Calculation performed with $\mathrm{Ag}(\mathrm{I})$ substituted for $\mathrm{Cu}(\mathrm{I})$.

Our initial catalyst designs are an extension of the amino acid-derived heterocyclic systems that we initially designed for asymmetric aldol reactions $[11,12]$. We reasoned that precatalysts with tridentate metal binding motifs would form more stable complexes with predictable coordination geometries, relative to the bidentate systems we explored previously. We also reasoned that heterocycles could act as hemilabile ligands, thus increasing flexibility during parts of the catalytic cycle and potentially permitting the relief of macrocyclic ring strain. Physical and computer models indicated that complexes with general structure 4 containing a 5 -membered heterocycle (Table 2 ) may be able to access favorable transition state geometries for $\mathrm{C} \_\mathrm{C}$ bond formation, but importantly should not undergo self-quenching whereby the amine (or intermediate enamine) can coordinate (and poison) the $\mathrm{Cu}(\mathrm{I})$ in an intramolecular fashion. 
The addition of the enamine to the alkyne could proceed in a syn or antifashion, to generate the organometallic adducts cis-(5) or trans-(6) (Table 2). Using acetone and acetylene as reaction partners, formation of the cisadducts was consistently calculated to be more exergonic than the transadducts, presumably due to increased ring strain in the trans adducts. Assuming that both transition states are feasible, and that the difference in alternative transition state energies would be proportional to the enthalpy differences between the cis and trans adducts (Bell-Evans-Polanyi principle) [43], we would expect the cis adducts to form preferentially.

Variation of the heterocycle was also explored computationally. Using a glycine-derived catalyst with a phenolate as the "eastern" ligand, calculations with imidazoles, oxazoles, and thiazoles as "western" ligands were undertaken (entries 1-6). The free energy changes with the thiazoles were most favorable among these examples, with the cis-adduct calculated to be $-2.9 \mathrm{kcal} / \mathrm{mol}$ lower in energy than the alkyne complex (entry 5). The analogous proline-derived catalyst was also computed to give the cis-adduct preferentially (entry 7).

Examination of the amine portion of the ligand revealed that the $N$-benzyl derived precatalyst (e.g. entry 9) was favored over the $\mathrm{N}$-methyl or proline-derived precatalysts (entries 5,7 ), with the free energy change for the formation of the cis-adduct calculated to be $-3.8 \mathrm{kcal} / \mathrm{mol}$ (entry 9). It was hypothesized that the increased steric bulk with the $N$-benzyl substituent would also help prevent undesirable 2:1 ligand-metal complexes observed by us with other precatalysts synthesized for asymmetric aldol reactions [12]. The proline-based precatalyst was calculated to be less favorable $(\Delta G=-2.1 \mathrm{kcal} / \mathrm{mol})$ (entry 7$)$, presumably due to the increased strain on the macrocyclic adduct structure from the constrained nature of the amine. The eastern portion of the precatalyst was also examined via introduction of phenolate, quinoline, and phosphine moieties (entries 9-15). Consistent with the previous trend, the cis-adducts of the $N$-benzyl quinoline-based precatalyst (e.g. entry 11 , $\Delta G=-10.2 \mathrm{kcal} / \mathrm{mol}$ ) were calculated to be favored over the proline analogs (e.g. entry $13,-5.5 \mathrm{kcal} / \mathrm{mol}$ ). Additionally, we reason that the more favorable free energy changes calculated with the quinoline- and phosphine-based catalysts is due to the increased cationic character of the metal center, relative to the phenolate complexes (e.g. entry 11 and 15 vs entry 5). The diphenylphosphine analogs (e.g. entry 15) gave similar results to the quinolines, and also provided the only favorable result for a trans-adduct (entry 16). Unfortunately, initial attempts to synthesize the desired phosphine-based precatalysts failed due to oxidation of the phosphine during column chromatography.

We also explored the use of $\mathrm{Ag}(\mathrm{I})$ as a metal salt (entry 17). Although formation of the $\mathrm{C} \_\mathrm{C}$ bond was calculated to be significantly more favorable than with the analogous $\mathrm{Cu}(\mathrm{I})$ complex (entries $11 \mathrm{vs} \mathrm{17),}$ comparison of the orientation of the enamine to the coordinated alkyne suggested that $\mathrm{Cu}(\mathrm{I})$ could be a more suitable choice as the enamine and alkyne were perpendicular to each other in the t-shaped $\mathrm{Ag}(\mathrm{I})$ complex, and unlikely to access a reactive conformation with suitable orbital overlap(Fig. S1). However, since these were ground state calculations, and not necessarily reflective of a transition state that might or might not be accessible, we included both $\mathrm{Cu}(\mathrm{I})$ and $\mathrm{Ag}(\mathrm{I})$ in our reaction screens (vide infra).

To confirm that more complex alkynes might also be feasibly used, we performed DFT calculations using 1butyne as an acceptor (Table S1). The results with acetone and 1-butyne predict thermodynamically favorable adduct formations. Calculations were run for the cis-adduct only for these substrates for comparative purposes given the trend observed in Table 2showing the trans-adduct to be less favorable in almost all cases. Addition to the terminal carbon of the alkyne (giving adduct 8) or internal carbon (giving 9) was compared with two quinoline-based complexes (Table S1), and the addition to the terminal alkyne carbon was predicted to be more favorable with both. In addition to favorable thermodynamic transformation from enamine complex to adduct, we also wished to examine the distance and orientation of the enamine with respect to the alkyne in the alkyne complex (e.g. 10, Fig. S2). Even though we did not attempt to determine transition state structures, it appears that the enamine and alkyne could adopt suitable positions for productive reactions. In adduct complexes such 
as 11, we commonly observed de-coordination of the thiazole nitrogen from the metal center. The hemilabile nature of this coordination may allow the adduct to adopt a macrocyclic species with reduced strain.

\subsection{Synthesis of precatalysts}

Our next objective was to develop modular syntheses of desirable heterocyclic precatalysts. Our results are summarized in Scheme 1, Scheme 2. Based on our DFT calculations, we focused on thiazole-containing precatalysts, initially using $N$-Boc glycine (12) as starting material (Scheme 1). Amide coupling with threonine methyl ester 13, followed by Dess-Martin Periodinane (DMP) oxidation, yielded the known dipeptidyl ketone 16 in good yield. Heating with Lawesson's reagent provided the thiazole 17[44], followed by $N$ benzylation using sodium hydride and benzyl bromidein DMF to give 18. Reduction of the ester proceeded cleanly with sodium borohydride and catalytic sodium triacetoxyborohydride. Mesylation of the primary alcohol (19) and addition of sodium azide generated azide 20, which was reduced with hydrogen and catalytic palladium on carbon. The resulting primary amine $\mathbf{2 1}$ could be combined in a modular fashion using reductive alkylation (amination) conditions with a variety of aldehydes to generate final precatalysts (22ad) after Boc removal. Reductive amination of the quinoline-based precatalysts in THF was complicated by the prominent formation of bis-alkylated byproducts which were not easily separable by column chromatography. Stepwise attempts to reduce the pre-formed imine with sodium borohydride yielded identical results. The use of acetic acid as a solvent was discovered to suppress the formation of the overalkylated byproduct, though reactions with these substrates were difficult to push to completion. A sulfonic acid resin (Amberlyst $15^{\circ}$ ) was effective for both Boc removal and trapping the final diamine products, which allowed impurities to be washed away and the desired products released in high purity after basification with ammonia in methanol. Analogous proline-based precatalysts (29a-d) were generated using an identical strategy, with similar results (Scheme 2).

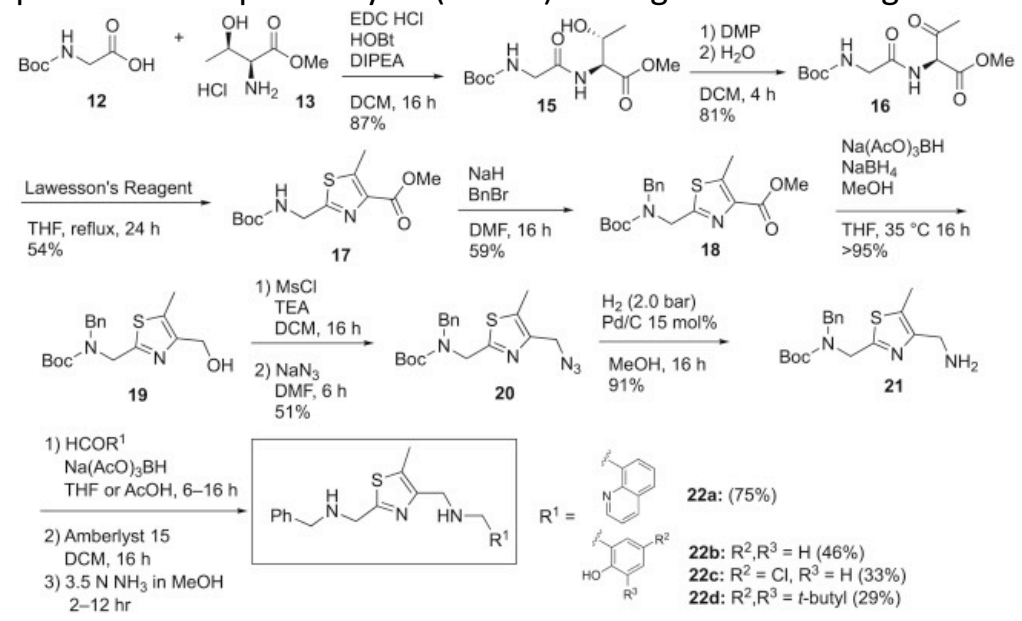

Scheme 1. Synthesis of glycine-based precatalysts.

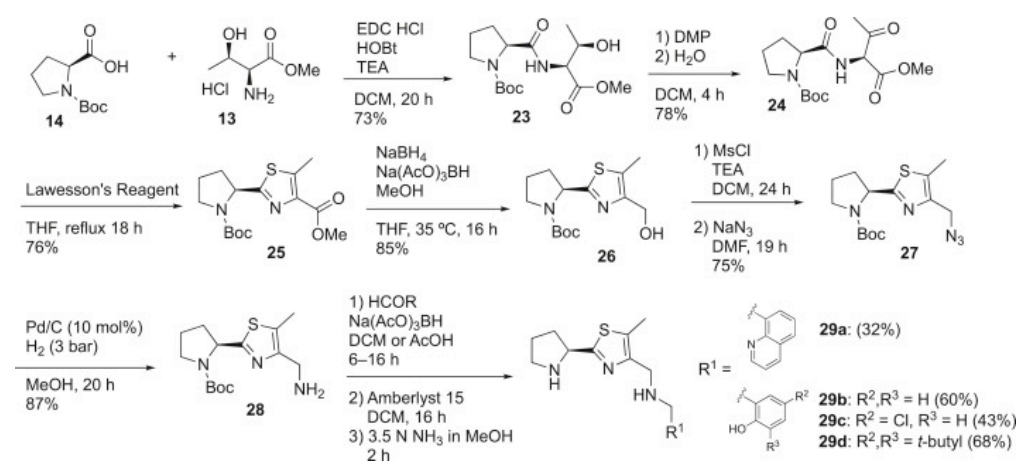

Scheme 2. Synthesis of proline-based precatalysts. 


\subsection{Reaction screening}

With a focused library of precatalysts in hand, we proceeded to test them in a variety of reaction screens, utilizing GC-MS to analyze each reaction. For initial screening, cyclopentanone was selected due to its wellestablished reactivity for enamine formation $[45,46]$. Internal alkynes were chosen as initial substrates due to the possibility that terminal alkynes may form undesired copper-acetylide species. Results from a representative solvent screen with precatalyst 22a are given in Table 3. Polar solvents(entries 1-6) yielded no reaction at $50{ }^{\circ} \mathrm{C}$. It is plausible that the coordinating nature of these solvents prevented interaction of the metal salt with the substrates. Chloroform and toluene (entries 7-10) also showed only starting material after reaction at $50{ }^{\circ} \mathrm{C}$. Nitromethane and THF (entries 13-16) produced an unknown, undesired byproduct that was also present in a control reaction run in THF where the hexyne had been omitted (entry 17). DCE and dioxane (entries 18-21) led to consumption of cyclopentanone, but gave complex, intractable mixtures of products. Given the use of DCE in the analogous intramolecular carbocyclization reactions, we explored additional substrates in this solvent with our library of precatalysts (Table 4). This screening showed that phenol based precatalysts (22b-d and 29bd) were inactive under the reaction conditions. Quinoline-based precatalysts (22a and 29a) showed complex mixtures of products. Analysis of these mixtures showed that GC-MS peaks were common amongst reactions with shared substrates. For example, reactions with acetone (Table 4, entries 1-5) contained a similar mixture of common byproducts. Similarly, reactions with 2-hexyne (entries $4,9,14,19$ ) also yielded a set of common byproducts that did not correspond to any desired products nor their derivatives, such as multiple alkenylationproducts, as determined by GC-MS and NMR of scaled up reactions. No GC-MS peaks were identified that were unique to a specific set of substrates, which would have suggested a unique and potentially desirable reaction. Based on the GC-MS data, we believe that the products formed under these conditions are primarily due to carbonyl-carbonyl or alkyne-alkyne coupling reactions. GC-MS evidence for aldol selfcondensation products was observed in some cases, most notably when phenylacetaldehyde was used as the carbonyl compound (entries 11-15). A second prominent byproduct seen via GC-MS for samples that contained phenylacetylene (entries 1, 6, 11, 16) was 1,4-diphenylbutadiyne. The presence of this byproduct in these samples was confirmed by comparison of the GC-MS traces to that of a commercial sample of 1,4diphenylbutadiyne. Additionally, select reactions were run with $\mathrm{AgBF}_{4}$ as the metal salt instead of $\left(\mathrm{CH}_{3} \mathrm{CN}\right)_{4} \mathrm{CuBF}_{4}$ (entries 21-26), under the conditions of Table 4. No reactions were observed in any of these cases.

Table 3. Solvent screen.

\begin{tabular}{|l|l|l|}
\hline \\
\hline Entry
\end{tabular}




\begin{tabular}{|l|l|l|l|}
\hline 13 & nitromethane & $\mathrm{Ph}$ & $\mathrm{C}$ \\
\hline 14 & nitromethane & \\
\hline 15 & THF & $\left(\mathrm{CH}_{2}\right)_{2} \mathrm{Me}$ & $\mathrm{C}$ \\
\hline 16 & THF & $\mathrm{Ph}$ & $\mathrm{C}$ \\
\hline 17 & THF & $\left(\mathrm{CH}_{2}\right)_{2} \mathrm{Me}$ & $\mathrm{C}$ \\
\hline 18 & dioxane & no alkyne & $\mathrm{C}$ \\
\hline 19 & dioxane & $\mathrm{Ph}$ & B \\
\hline 20 & DCE & $\left(\mathrm{CH}_{2}\right)_{2} \mathrm{Me}$ & B \\
\hline 21 & DCE & $\mathrm{Ph}$ & B \\
\hline
\end{tabular}

${ }^{a}$ In a glovebox, precatalyst 22a $(2 \mathrm{mg}, 0.005 \mathrm{mmol})$ was dissolved in DCE $(0.5 \mathrm{~mL})$ and added to $\left(\mathrm{CH}_{3} \mathrm{CN}\right)_{4} \mathrm{CuBF}_{4}(0.005 \mathrm{mmol})$ in a $1.5 \mathrm{~mL} \mathrm{HPLC}$ vial. The alkyne $(0.130 \mathrm{mmol})$ and carbonyl compound $(0.026 \mathrm{mmol})$ were added as solutions in DCE $(0.150$ and $0.100 \mathrm{~mL}$, respectively). The vials were removed from the glovebox and shaken at $50{ }^{\circ} \mathrm{C}$ for $16 \mathrm{~h}$. Crude reaction mixtures were condensed and analyzed directly by GC-MS.

${ }^{b}$ Results: A: No reaction; B: complex mixture; C: carbonyl-derived byproducts observed, as determined by a control reaction without the alkyne.

${ }^{\mathrm{c}}$ Reaction heated to $95^{\circ} \mathrm{C}$.

${ }^{\mathrm{d}}$ Samples were diluted with $5 \mathrm{~mL}$ water and extracted with ether $(3 \times 2 \mathrm{~mL})$, before being condensed and analyzed by GC-MS.

Table 4. Representative reaction screen in DCE .
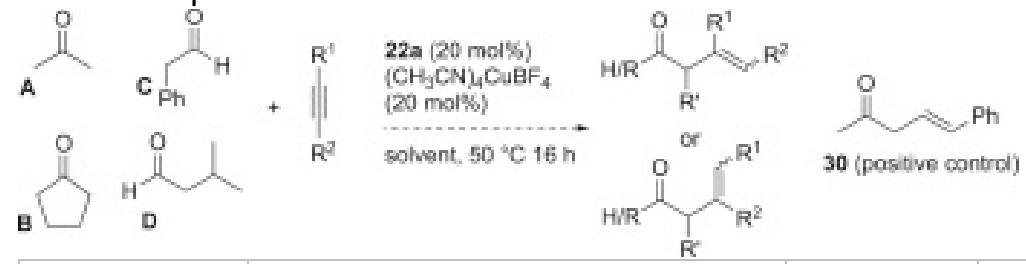

\begin{tabular}{|c|c|c|c|c|}
\hline Entry ${ }^{a}$ & Aldehyde/ketone & $R[1]$ & $\mathbf{R}[2]$ & Result $^{b}$ \\
\hline 1 & A & $\mathrm{H}$ & $\mathrm{Ph}$ & $A, B, C$ \\
\hline 2 & A & $\mathrm{Me}$ & $\mathrm{Ph}$ & B \\
\hline 3 & $A$ & $\mathrm{H}$ & $\left(\mathrm{CH}_{2}\right)_{2} \mathrm{Me}$ & B \\
\hline 4 & A & $\mathrm{Me}$ & $\left(\mathrm{CH}_{2}\right)_{2} \mathrm{Me}$ & B \\
\hline 5 & A & $\mathrm{H}$ & TMS & B \\
\hline 6 & B & $\mathrm{H}$ & $\mathrm{Ph}$ & $A, B, C$ \\
\hline 7 & B & $\mathrm{Me}$ & $\mathrm{Ph}$ & B \\
\hline 8 & B & $\mathrm{H}$ & $\left(\mathrm{CH}_{2}\right)_{2} \mathrm{Me}$ & B \\
\hline 9 & B & $\mathrm{Me}$ & $\left(\mathrm{CH}_{2}\right)_{2} \mathrm{Me}$ & B \\
\hline 10 & B & $\mathrm{H}$ & TMS & B \\
\hline 11 & $\mathrm{C}$ & $\mathrm{H}$ & $\mathrm{Ph}$ & $A, B, C$ \\
\hline 12 & $\mathrm{C}$ & $\mathrm{Me}$ & $\mathrm{Ph}$ & B \\
\hline 13 & $\mathrm{C}$ & $\mathrm{H}$ & $\left(\mathrm{CH}_{2}\right)_{2} \mathrm{Me}$ & B \\
\hline 14 & $\mathrm{C}$ & $\mathrm{Me}$ & $\left(\mathrm{CH}_{2}\right)_{2} \mathrm{Me}$ & B \\
\hline 15 & $\mathrm{C}$ & $\mathrm{H}$ & TMS & B \\
\hline 16 & $D$ & $\mathrm{H}$ & $\mathrm{Ph}$ & $A, B, C$ \\
\hline 17 & $\mathrm{D}$ & $\mathrm{Me}$ & $\mathrm{Ph}$ & $\mathrm{B}, \mathrm{C}$ \\
\hline 18 & D & $\mathrm{H}$ & $\left(\mathrm{CH}_{2}\right)_{2} \mathrm{Me}$ & $\mathrm{B}, \mathrm{C}$ \\
\hline 19 & $\mathrm{D}$ & $\mathrm{Me}$ & $\left(\mathrm{CH}_{2}\right)_{2} \mathrm{Me}$ & $B, C$ \\
\hline 20 & $D$ & $\mathrm{H}$ & TMS & $B, C$ \\
\hline $21^{c}$ & A & $\mathrm{H}$ & $\left(\mathrm{CH}_{2}\right)_{2} \mathrm{Me}$ & $\mathrm{D}$ \\
\hline $22^{c}$ & $A$ & $\mathrm{Me}$ & $\left(\mathrm{CH}_{2}\right)_{2} \mathrm{Me}$ & $D$ \\
\hline
\end{tabular}




\begin{tabular}{|l|l|l|l|l|}
\hline $23^{c}$ & B & H & $\left(\mathrm{CH}_{2}\right)_{2} \mathrm{Me}$ & D \\
\hline $24^{c}$ & B & Me & $\left(\mathrm{CH}_{2}\right)_{2} \mathrm{Me}$ & D \\
\hline $25^{c}$ & $\mathrm{C}$ & $\mathrm{H}$ & $\left(\mathrm{CH}_{2}\right)_{2} \mathrm{Me}$ & D \\
\hline $26^{c}$ & $\mathrm{C}$ & $\mathrm{Me}$ & $\left(\mathrm{CH}_{2}\right)_{2} \mathrm{Me}$ & D \\
\hline
\end{tabular}

${ }^{a}$ In a glovebox, precatalyst 22a $(2 \mathrm{mg}, 0.005 \mathrm{mmol})$ was dissolved in DCE $(0.5 \mathrm{~mL})$ and added to $\left(\mathrm{CH}_{3} \mathrm{CN}\right)_{4} \mathrm{CuBF}_{4}(0.005 \mathrm{mmol})$ in a $1.5 \mathrm{~mL} \mathrm{HPLC}$ vial. The alkyne $(0.130 \mathrm{mmol})$ and carbonyl compound $(0.026 \mathrm{mmol})$ were added as solutions in DCE $(0.150$ and $0.100 \mathrm{~mL}$, respectively). The vials were removed from the glovebox and shaken at $50{ }^{\circ} \mathrm{C}$ for $16 \mathrm{~h}$. Crude reaction mixtures were analyzed directly by GC-MS. ${ }^{b}$ Results: A: dimerization of alkyne; B: complex mixture; C: carbonyl-derived byproducts observed, as determined by a control reaction without the alkyne. $\mathrm{D}$ : no reaction.

${ }^{\mathrm{c}}$ Reaction run with $\mathrm{AgBF}_{4}$ instead of $\left(\mathrm{CH}_{3} \mathrm{CN}\right)_{4} \mathrm{CuBF}_{4}$.

To ensure that we could detect desired product formation, a control reaction was run to confirm that trace amounts of desired product could be detected in our crude reaction mixtures via GC-MS. An authentic sample for the addition of acetone to phenylacetylene (30) was synthesized according to a protocol reported by Trofimov [47]. Two parallel reactions were set up containing acetone and phenylacetylene substrates (Table 4, entry 1), and one reaction was doped with the positive control (30) at $5 \mathrm{~mol} \%$. After stirring at $50{ }^{\circ} \mathrm{C}$ for $24 \mathrm{~h}$, both reactions were analyzed via GC-MS. The positive control was detected in the reaction that was doped and it was not detected in the undoped reaction.

A range of acidic additives were additionally tested for the addition of cyclopentanone to 2-hexyne, along with the non-coordinating base 2,6-di-tert-butylpyridine (Table 5). No reactions were observed in any cases that previously led to consumption of substrates, such as the control reaction with no additive (entry 7).

Table 5. Additives screen.

\begin{tabular}{|l|l|l|}
\hline \\
\hline Entry
\end{tabular}

${ }^{a}$ In a glovebox, precatalyst 22a $(2 \mathrm{mg}, 0.005 \mathrm{mmol})$ was dissolved in DCE $(0.5 \mathrm{~mL})$ and added to $\left(\mathrm{CH}_{3} \mathrm{CN}\right)_{4} \mathrm{CuBF}_{4}(0.005 \mathrm{mmol})$ in a $1.5 \mathrm{~mL} \mathrm{HPLC}$ vial. The alkyne $(0.130 \mathrm{mmol})$ and carbonyl compound $(0.026 \mathrm{mmol})$ were added as solutions in DCE $(0.150$ and $0.100 \mathrm{~mL}$, respectively). Next, additives $(0.005 \mathrm{mmol})$ were added as solutions in DCE $(0.100 \mathrm{~mL})$. The vials were removed from the glovebox and shaken at $50^{\circ} \mathrm{C}$ for $16 \mathrm{~h}$. Crude reaction mixtures were condensed and analyzed directly by GC-MS.

${ }^{b}$ Results: A: No reaction; B: complex mixture.

\subsection{X-ray crystal and NMR studies}

Concurrent with our efforts to screen catalysts and reaction conditions, we attempted to obtain single crystals of various $\mathrm{Cu}(\mathrm{I})$ complexes to corroborate our DFT studies. It was necessary to develop a protocol to cope with the 
additional challenge of keeping oxygen sensitive $\mathrm{Cu}(\mathrm{I})$ complexes in an inert atmosphere throughout the course of the crystallization (see Experimental Section). Unfortunately, attempts to obtain single crystals of $\mathrm{Cu}(\mathrm{I})$ complexes with our precatalysts have been unsuccessful. Crystallization trials were run with all precatalysts, however efforts focused mainly on $\mathbf{2 2 a}, \mathbf{2 9 a}$, and $\mathbf{2 9 d}$, particularly because $\mathbf{2 2 a}$ and $\mathbf{2 9 a}$ showed the greatest apparent reactivity in reaction screens. Due to its polar, non-coordinating nature, nitromethane was chosen as the strong solvent and ultimately a 1:1 nitromethane: benzene mixture was chosen as the strong solvent with ether or pentane as the weak solvent. Samples containing phenol-based precatalysts $\mathbf{2 2} \mathbf{b} \mathbf{b} \mathbf{d}$ and $\mathbf{2 9} \mathbf{b}-\mathbf{d}$ led to the formation of $\left(\mathrm{CH}_{3} \mathrm{CN}\right)_{4} \mathrm{CuBF}_{4}$ crystals in 1:1 nitromethane: benzene with either ether or pentane as the weak solvent. This observation suggests that ligand affinity for $\mathrm{Cu}(\mathrm{I})$ may not be as high as anticipated. Deprotonation of precatalysts $\mathbf{2 2} \mathbf{d}$ and $\mathbf{2 9 d}$ using $\mathrm{NaH}$ prior to complexation of $\left(\mathrm{CH}_{3} \mathrm{CN}\right)_{4} \mathrm{CuBF}_{4}$ yielded similar results. However, $\left(\mathrm{CH}_{3} \mathrm{CN}\right)_{4} \mathrm{CuBF}_{4}$ crystals were not observed in samples containing the quinoline-based precatalysts. In these cases, oiling out of the precatalyst was observed. Exploration of a range of $\mathrm{Cu}(\mathrm{I})$ salts as well as $\mathrm{Zn}(\mathrm{II}), \mathrm{Ag}(\mathrm{I})$, and $\mathrm{In}(\mathrm{III})$ salts with $22 \mathrm{2a}$ eventually yielded a $\mathrm{Ag}(\mathrm{I})$ crystal with a 2:2 ligand to metal stoichiometry (Fig. 4). Both ligands are bridging the $A g(I)$ ions, which are non-equivalent. Ag1 has a linear geometry via coordination from the $\mathrm{N}$-benzyl $\mathrm{N} 4$ and secondary $\mathrm{N} 6$ amino groups from two different ligands, but the complex could also be described as having a seesaw geometry with additional coordination possible from quinoline N5 and thiazole N3. Ag2 has a distorted trigonal planar coordination geometry (chelated by thiazole N7, secondary amine N8, and N-benzyl N2). It is also disordered in the structure, present in two different positions due to pyramidal inversion of the benzylamine nitrogen (N8). Of special note is that neither of the metals are coordinated to all three of the desired coordinating groups of the precatalyst, namely the quinoline, thiazole, and the secondary amine proximal to the quinoline. Coordination of the $N$-benzylamine (required as an aminocatalyst), instead of the quinoline, as observed in the bimetallic structure in Fig. 4, could provide an explanation for the lack of activity of this catalyst class.

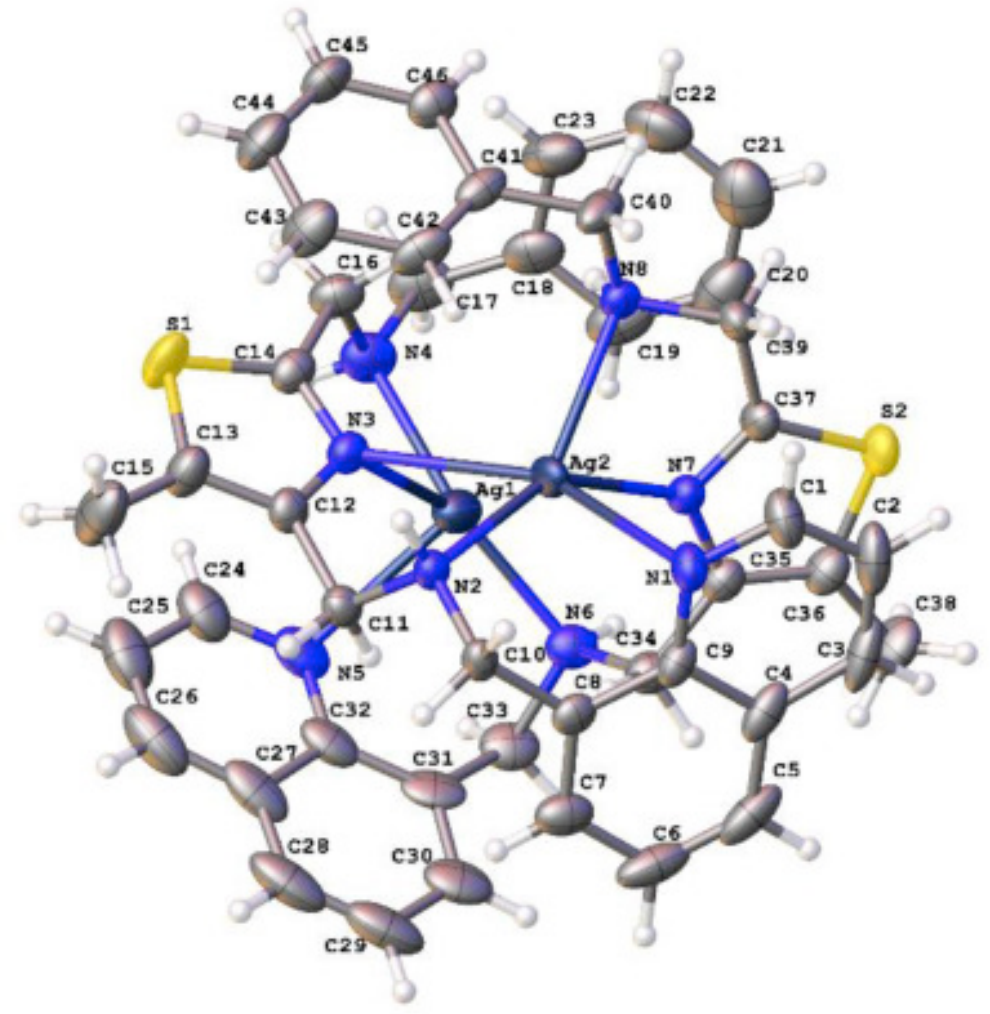

Fig. 4. X-ray structure of 2:2 complex of $22 \mathrm{a}$ and $\mathrm{AgBF}_{4}$.

The lack of a single, well-defined catalyst complex, as well as undesired coordination of the organocatalytic amine to metal centers, is also consistent with ${ }^{1} \mathrm{H}$ NMR experiments. Addition of $\left(\mathrm{CH}_{3} \mathrm{CN}\right)_{4} \mathrm{CuBF}_{4}$ to bifunctional precatalyst 22a in $\mathrm{CD}_{3} \mathrm{NO}_{2}$, with the sample prepared in the glovebox to inhibit $\mathrm{Cu}(\mathrm{II})$ formation, showed 
significant broadening of the ligand peaks with subtle chemical shift changes in the quinoline proton signals of roughly $0.1 \mathrm{ppm}$ (see Supporting Information, Fig. S3). Addition of phenylacetylene further broadened the ligand peaks almost completely into the baseline with a minor additional downfield shift of the most downfield quinoline proton. The acetylene proton was also slightly shifted from its original position, however it is unknown if this shift is due to interaction with ligand-bound or free copper (I). Broadening of the ligand (precatalyst) peaks upon addition of the metal is indicative of a slow exchange (on the NMR timescale) between different complexes. The lack of discrete and characterizable $\mathrm{Cu}(\mathrm{I})$ complexes may be due to diverse coordination complexes that may be facilitated by the organocatalytic amine. We hypothesize that alternative coordination geometries, in particular hindered square planar complexes, may be more suitable for promoting intermolecular direct additions to alkynes.

\section{Conclusions}

We have investigated a strategy for the design and prioritization of potential bifunctional catalysts using as a guide DFT calculations of putative catalytic intermediates before and after $\mathrm{C} \_\mathrm{C}$ bond formation. This strategy was applied for the first time to novel $\mathrm{Cu}(\mathrm{I})$ complexes containing tridentate, heterocyclic ligands. We conclude that the designed bifunctional systems may not have sufficient affinity for $\mathrm{Cu}(\mathrm{I})$, or may undergo a range of dynamic coordination modes that precludes the formation of effective catalysts or well-characterizable complexes suitable for the desired direct additions of aldehydes and ketones to alkynes. Studies continue in our laboratories using alternative scaffolds with significantly greater rigidity.

\section{Experimental section}

\subsection{General information: DFT calculations}

Starting points for enamine-alkyne complex calculations were set by starting with the enamine-Cu(I)-acetylene complex (before $\mathrm{C} \_\mathrm{C}$ bond formation) and adduct (after $\mathrm{C} \_\mathrm{C}$ bond formation) from Table 2, entry 5 . These complexes were drawn within the Avogadro [48] molecular visualization program and subjected to preliminary optimization with molecular mechanics. The alkyne and enamine carbons were fixed at a specific orientation and distance while the rest of the molecule was optimized using the auto-optimization feature (force field set to UFF, 4 steps per update, and steepest descent algorithm). The resulting coordinates were added to the Gaussian 09 input file for DFT calculations. Subsequent calculations of different precatalysts/substrates were preoptimized in Avogadro as described above, while keeping the enamine-alkyne starting orientation and distance from the original calculation constant. Starting adduct complexes were preoptimized using molecular mechanics as described above.

Geometries were then optimized and energies were calculated by DFT using the B3PW91 functional and the basis sets LANL2DZ for all metals and cc-pVDZ for other atoms, using the PCM solvation model with dichloromethane. Enthalpies and free energies were calculated at $298.15 \mathrm{~K}$ using unscaled harmonic vibrational frequencies. All calculations were performed with Gaussian 09 on the Père cluster at Marquette University.

\subsection{General information: synthesis}

A Vacuum Atmospheres Co. Omni-Lab glovebox was used for weighing out air sensitive materials, as noted in the detailed protocols. All reactions utilized magnetic stirring unless otherwise noted.

All reagents and solventswere purchased from commercial vendors and used as received. NMR spectra were recorded on Varian $300 \mathrm{MHz}$ or $400 \mathrm{MHz}$ spectrometers as indicated. Proton and carbon chemical shifts are reported in parts per million (ppm; $\delta$ ) relative to tetramethylsilane, $\mathrm{CDCl}_{3}$, or DMSO- $d_{6}\left({ }^{1} \mathrm{H} \delta 0,{ }^{13} \mathrm{C} \delta 77.16\right.$, or ${ }^{13} \mathrm{C} \delta 39.5$, respectively). NMR data are reported as follows: chemical shifts, multiplicity (obs = obscured, 
app = apparent, $\mathrm{br}=$ broad, $\mathrm{s}=$ singlet, $\mathrm{d}=$ doublet, $\mathrm{t}=$ triplet, $\mathrm{q}=$ quartet, sxt = sextet, $\mathrm{m}=$ multiplet, comp = complex overlapping signals); coupling constant(s) in $\mathrm{Hz}$; integration. Unless otherwise indicated, NMR data were collected at $25^{\circ} \mathrm{C}$. Flash chromatography was performed using Biotage SNAP cartridges filled with 40$60 \mu \mathrm{m}$ silica gel, or $\mathrm{C} 18$ reverse phase columns (Biotage ${ }^{\circ}$ SNAP Ultra C18 or Isco Redisep ${ }^{\circ} \mathrm{Gold}$ C18Aq) on Biotage Isolera systems, with photodiode array UV detectors. Analytical thin layer chromatography (TLC) was performed on Agela Technologies glass plates with $0.25 \mathrm{~mm}$ silica gel with F254 indicator. Visualization was accomplished with UV light $(254 \mathrm{~nm})$ and aqueous potassium permanganate $\left(\mathrm{KMnO}_{4}\right)$ stain followed by heating, unless otherwise noted. Tandem liquid chromatography/mass spectrometry (LC-MS) was performed on a Shimadzu LCMS-2020 with autosampler, photodiode array detector, and single-quadrupole MS with ESI and APCl dual ionization, using a Peak Scientific nitrogen generator. Unless otherwise noted, a standard LCMSmethod was used to analyze reactions and reaction products: Phenomenex Gemini C18 column $\left(100 \times 4.6 \mathrm{~mm}, 3 \mu \mathrm{m}\right.$ particle size, $110 \mathrm{~A}$ pore size); column temperature $40^{\circ} \mathrm{C} ; 5 \mu \mathrm{L}$ of sample in $\mathrm{MeOH}$ or $\mathrm{CH}_{3} \mathrm{CN}$ at a nominal concentration of $1 \mathrm{mg} / \mathrm{mL}$ was injected, and peaks were eluted with a gradient of 25-95\% $\mathrm{CH}_{3} \mathrm{CN} / \mathrm{H}_{2} \mathrm{O}$ (both with $0.1 \%$ formic acid) over 5 min, then $95 \% \mathrm{CH}_{3} \mathrm{CN} / \mathrm{H}_{2} \mathrm{O}$ for 2 min. Purity was measured by UV absorbance at 210 or $254 \mathrm{~nm}$. High-resolution mass spectra were obtained at the University of WisconsinMilwaukee Mass Spectrometry Laboratory with a Shimadzu LCMS-IT-TOF with ESI and APCI ionization. Gas chromatography/mass spectrometry (GC-MS) was performed with Agilent Technologies $6850 \mathrm{GC}$ with $5973 \mathrm{MS}$ detector, and Agilent HP-5S or Phenomenex Zebron ZB-5MSi Guardian columns ( $30 \mathrm{~m}, 0.25 \mathrm{~mm}$ ID, $0.25 \mu \mathrm{m}$ film thickness). Preparative HPLC was performed on a Shimadzu LC-20AP preparative HPLC with autosampler, dual wavelength detector, and fraction collector. Method: Column: Phenomenex Gemini $\mathrm{C}_{18}$ semi-preparative ( $250 \times 10$ mm, $5 \mu \mathrm{m}$ particle size, 110 A pore size); Mobile Phase: Solvent A: $\mathrm{H}_{2} \mathrm{O}$ w/0.1\% formic acid; Solvent B: $\mathrm{MeOH}$ w/0.1\% formic acid; Peak collection: measured by UV absorbance at 210 or $254 \mathrm{~nm}$; Sample Injection: $0.3 \mathrm{~mL}$ (2 mL sample loop) of sample in DMSO; Flow Rate: $6.0 \mathrm{~mL} / \mathrm{min}$; Gradient: 0-1.5 min: 25\% MeOH, 1.5 min-12 min: 25\%-95\% MeOH, 12 min-19 min: 95\% MeOH. IR spectra were obtained as a thin film on ZnSe plate using a Thermo Scientific Nicolet iS5 spectrometer. Optical rotations were measured with a Rudolph Research Analytical Autopol polarimeter at $\lambda=589 \mathrm{~nm}$, using a $2 \mathrm{~mL}$ cell with $10 \mathrm{~cm}$ path length. Specific rotations are reported as follows: $[\alpha]_{D}{ }^{\top} \mathrm{C}\left(\mathrm{c}=\mathrm{g} / 100 \mathrm{~mL}\right.$, solvent). A VWR ${ }^{\circ}$ Analog vortex mixer fitted with a $5 \times 5^{\prime \prime}$ sample box with divider was used to shake reaction samples.

Alkyne and carbonyl stock solutions used for screening were made outside of the glovebox and purged with argon for $10 \mathrm{~min}$ before being brought into the glovebox for use. Ligand solutions for crystallizations of $\mathrm{Cu}(\mathrm{I})$ complexes were made on the benchtop and purged with argon for $10 \mathrm{~min}$ before being brought into the glovebox for use.

\subsection{Synthesis of precatalysts}

\subsubsection{Methyl (2S,3R)-2-(2-\{[(tert-butoxy)carbonyl]amino\}acetamido)-3-hydroxybutanoate (15)}

$\mathrm{N}$-Boc glycine (12) $(6.28 \mathrm{~g}, 35.9 \mathrm{mmol})$ and L-threonine methyl ester, $\mathrm{HCl}$ salt (13) $(6.08 \mathrm{~g}, 35.9 \mathrm{mmol})$ were added to a $500 \mathrm{~mL}$ round bottom flask with stir bar and dissolved with DCM ( $250 \mathrm{~mL})$. HOBt (6.04 g, $39.4 \mathrm{mmol})$ was added followed by DIPEA (15.6 $\mathrm{mL}, 89.6 \mathrm{mmol})$, and sealed with a septum. The reaction stirred for $3 \mathrm{~min}$ until the solids dissolved, then $\operatorname{EDC~HCl}(7.56 \mathrm{~g}, 39.4 \mathrm{mmol})$ was added. The reaction stirred for $16 \mathrm{~h}$. A sample aliquot was taken from the reaction, dissolved in $1 \mathrm{~mL} \mathrm{HPLC}$ grade MeCN, and analyzed with LCMS to confirm reaction completion. The reaction was washed with half saturated sodium bicarbonate $(2 \times 250 \mathrm{~mL})$, and $0.1 \mathrm{~N}$ $\mathrm{HCl}(2 \times 250 \mathrm{~mL})$. The combined aqueous washes were saturated with $\mathrm{NaCl}$ and extracted with EtOAc $(3 \times 250 \mathrm{~mL})$. The combined organics were washed with brine dried over sodium sulfate, filtered, and condensed to give the title compound as a clear oil $(8.00 \mathrm{~g}, 77 \%)$. The crude product was pushed forward without further purification. This compound has been previously reported and characterized (CAS\# 67864-88-4). ${ }^{1} \mathrm{H}$ NMR $\left(400 \mathrm{MHz} \mathrm{CDCl}_{3}\right) \delta=1.20(\mathrm{~d}, J=8.2 \mathrm{~Hz}, 3 \mathrm{H}), 1.45(\mathrm{~s}, 9 \mathrm{H}), 3.75(\mathrm{~s}, 3 \mathrm{H}), 3.88(\mathrm{br} \mathrm{s}, 2 \mathrm{H}), 4.34(\mathrm{br} \mathrm{s}, 1 \mathrm{H}), 4.58$ $(\mathrm{d}, J=8.6 \mathrm{~Hz}, 1 \mathrm{H}), 5.72(\mathrm{br} \mathrm{s}, 1 \mathrm{H}), 7.26(\mathrm{~d}, J=8.2 \mathrm{~Hz}, 1 \mathrm{H})$. 
4.3.2. Methyl (2S)-2-(2-\{[(tert-butoxy)carbonyl]amino\}acetamido)-3-oxobutanoate (16)

Alcohol 15 ( $7.20 \mathrm{~g}, 24.9 \mathrm{mmol})$ was added to a $1 \mathrm{~L}$ round bottom flask with stir bar followed by DCM (600 $\mathrm{mL}$ ) and Dess-Martin periodinane (12.62 g, $29.8 \mathrm{mmol})$. The flask was sealed with a septum and purged with nitrogen. The reaction was stirred for $1.5 \mathrm{~h}$ before water $(0.45 \mathrm{~mL}, 24.8 \mathrm{mmol})$ was added, and the reaction stirred for another $3 \mathrm{~h}$. A sample aliquot was taken from the reaction, dissolved in $1 \mathrm{~mL}$ HPLC grade MeCN, and analyzed with LC-MS to confirm reaction completion. The reaction was poured on to a $10 \%$ sodium thiosulfate solution $(400 \mathrm{~mL}$ ) and stirred for $20 \mathrm{~min}$. The organic layer was separated, washed with saturated aq. sodium bicarbonate $(2 \times 250 \mathrm{~mL})$ and brine, then dried over sodium sulfate, filtered, and condensed to give the title compound as a yellow oil $(5.80 \mathrm{~g}, 81 \%)$. The crude product was pushed forward without further purification. This compound has been previously reported and characterized (CAS\# 1166831-50-0).

\subsubsection{Methyl 2-(\{[(tert-butoxy)carbonyl]amino\}methyl)-5-methyl-1,3-thiazole-4-carboxylate (17)} Ketone 16 ( $5.84 \mathrm{~g}, 20.3 \mathrm{mmol})$ was added to a $250 \mathrm{~mL}$ round bottom flask with stir bar followed by anhydrous THF (150 mL) under a nitrogen atmosphere. Lawesson's Reagent (12.29 g, $30.4 \mathrm{mmol})$ was added and the flask was fitted with a reflux condenser before the apparatus was sealed with a septum and purged with nitrogen for $15 \mathrm{~min}$, before being heated to reflux for $16 \mathrm{~h}$. A sample aliquot was taken from the reaction, dissolved in $1 \mathrm{~mL}$ $\mathrm{HPLC}$ grade MeCN, and analyzed with LC-MS to confirm reaction completion. The reaction was condensed to an oil, then dissolved in EtOAc $(250 \mathrm{~mL})$ and washed with saturated sodium bicarbonate $(2 \times 250 \mathrm{~mL})$. The aqueous washes were extracted with EtOAc $(100 \mathrm{~mL})$, and the combined organics were washed with brine and condensed to a yellow oil. The oil was adsorbed onto $\mathrm{SiO}_{2}(25 \mathrm{~g})$, then purified by flash chromatography (100 g $\mathrm{SiO}_{2}$ cartridge; 0-100\% EtOAc/hexanes gradient) to yield the title compound as a yellow oil (3.12 g, 53\%). This compound has been previously reported and characterized (CAS\# 232280-95-4). ${ }^{1} \mathrm{H}$ NMR (400 MHz, $\left.\mathrm{CDCl}_{3}\right) \delta=1.47(\mathrm{~s}, 9 \mathrm{H}), 2.74(\mathrm{~s}, 3 \mathrm{H}), 3.92(\mathrm{~s}, 3 \mathrm{H}), 4.55(\mathrm{~s}, 2 \mathrm{H}), 5.47(\mathrm{br} \mathrm{s}, 1 \mathrm{H})$.

4.3.4. Methyl 2-(\{benzyl[(tert-butoxy)carbonyl]amino\}methyl)-5-methyl-1,3-thiazole-4-carboxylate (18) Carbamate 17 ( $3.00 \mathrm{~g}, 10.5 \mathrm{mmol}$ ) was added to an oven dried $250 \mathrm{~mL}$ round bottom flask with stir bar containing $4 \AA$ A molecular sieves $(1.0 \mathrm{~g})$. The flask was sealed with a septum and flushed with nitrogen, then anhydrous DMF $(75 \mathrm{~mL})$ was added. After $1 \mathrm{~h}$ the DMF solution was syringed away from the sieves into a second $250 \mathrm{~mL}$ oven round bottom flask with stir bar sealed under nitrogen. The sieves were rinsed with DMF under nitrogen $(1 \times 10 \mathrm{~mL})$. Benzyl bromide $(1.65 \mathrm{~mL}, 9.63 \mathrm{mmol})$ was added via syringe followed by $\mathrm{NaH}(0.545 \mathrm{~g}$, $13.6 \mathrm{mmol})$. The reaction was stirred for $16 \mathrm{~h}$ under nitrogen. A sample aliquot was taken from the reaction, dissolved in $1 \mathrm{~mL} \mathrm{HPLC}$ grade MeCN, and analyzed with LC-MS to confirm reaction completion. The reaction was diluted with ether $(250 \mathrm{~mL})$, quenched with saturated aqueous ammonium chloride $(150 \mathrm{~mL})$, then diluted with water $(750 \mathrm{~mL})$. The organic layer was separated and the aqueous layer was saturated with solid $\mathrm{NaCl}$, then extracted with ether $(2 \times 75 \mathrm{~mL})$. The combined organics were washed with brine, dried over sodium sulfate, filtered, and condensed to afford a light brown oil. The crude was purified by flash chromatography $(50 \mathrm{~g}$ $\mathrm{SiO}_{2}$ cartridge; 0-45\% EtOAc/hexanes gradient) to give the title compound as a yellow oil ( $\left.2.30 \mathrm{~g}, 58 \%\right)$. TLC $\mathrm{R}_{\mathrm{f}}=0.33\left(70: 30\right.$ hexane:EtOAc); ${ }^{1} \mathrm{H}$ NMR $\left(300 \mathrm{MHz}, \mathrm{CDCl}_{3}\right) \delta=1.33-1.73(\mathrm{~m}, 9 \mathrm{H}), 1.51(\mathrm{~s}, 9 \mathrm{H}), 2.75(\mathrm{~s}, 3 \mathrm{H}), 3.93$ $(\mathrm{s}, 3 \mathrm{H}), 4.48(\mathrm{~s}, 2 \mathrm{H}), 4.63(\mathrm{~d}, J=1.0 \mathrm{~Hz}, 2 \mathrm{H}), 7.28(\mathrm{t}, J=8.8 \mathrm{~Hz}, 5 \mathrm{H}) ;{ }^{13} \mathrm{C}$ NMR is complicated due to rotamers. ${ }^{13} \mathrm{C}$ $\operatorname{NMR}\left(75 \mathrm{MHz}, \mathrm{CDCl}_{3}\right) \delta=13.4,28.6,48.4,50.3,51.1,52.3,81.3,127.7,128.4,128.8,137.5,140.5,145.9,146.5$, 155.2, 155.8, 163.0, 164.9, 165.5; IR (film) 2972, 1696, 1157, $700 \mathrm{~cm}^{-1}$; HRMS (ESI ${ }^{+}$) calculated for $\mathrm{C}_{19} \mathrm{H}_{24} \mathrm{~N}_{2} \mathrm{O}_{4} \mathrm{~S}$ $[\mathrm{M}+\mathrm{H}] 377.1535$, found 377.1497 .

\subsubsection{Tert-butyl $\boldsymbol{N}$-benzyl- $\boldsymbol{N}$ - $\{[4$-(hydroxymethyl)-5-methyl-1,3-thiazol-2-yl]methyl\}carbamate (19)}

Ester $18(2.00 \mathrm{~g}, 5.31 \mathrm{mmol})$ was added to an oven dried $100 \mathrm{~mL}$ round bottom flask with stir bar followed by sodium triacetoxyborohydride $(0.059 \mathrm{~g}, 0.27 \mathrm{mmol})$, and sodium borohydride $(0.433 \mathrm{~g}, 11.2 \mathrm{mmol})$. The flask was sealed with a septum and purged with nitrogen before anhydrous THF (30 mL) was added via cannula. The reaction was stirred for $5 \mathrm{~min}$, then anhydrous methanol $(0.86 \mathrm{~mL}, 21.3 \mathrm{mmol})$ was added via syringe over $5 \mathrm{~min}$. The reaction was heated at $35^{\circ} \mathrm{C}$ for $16 \mathrm{~h}$. A sample aliquot was taken from the reaction, dissolved in 
$1 \mathrm{~mL}$ HPLC grade MeCN, and analyzed with LC-MS to confirm reaction completion. The reaction was diluted with EtOAc $(50 \mathrm{~mL})$ and quenched with saturated aqueous ammonium chloride. The layers were separated and the aqueous layer was saturated with solid $\mathrm{NaCl}$, then extracted with $10 \% \mathrm{MeOH}$ in $\mathrm{DCM}(3 \times 75 \mathrm{~mL})$. The combined organics were washed with brine and condensed to give the title compound as a yellow oil (1.93 g, 104\%). The crude material was moved forward without purification. $T L C R_{f}=0.31$ (50:50 hexane:EtOAc); ${ }^{1} \mathrm{H} N M R(300 \mathrm{MHz}$, $\left.\mathrm{CDCl}_{3}\right) \delta=1.48(\mathrm{br} \mathrm{s}, 9 \mathrm{H}), 2.36(\mathrm{br} \mathrm{s}, 3 \mathrm{H}), 4.27-4.83(\mathrm{~m}, 6 \mathrm{H}), 7.26(\mathrm{~s}, 5 \mathrm{H}) ;{ }^{13} \mathrm{C} \mathrm{NMR}$ is complicated due to rotamers. ${ }^{13} \mathrm{C} \mathrm{NMR}\left(75 \mathrm{MHz}, \mathrm{CDCl}_{3}\right) \delta=11.2,28.6,47.7,47.9,50.1,50.8,58.0,77.5,81.1,127.6,127.8,128.4$, 128.7, 130.1, 130.4, 137.7, 137.9, 150.7, 155.3, 155.7, 165.1, 165.5; IR (film) 3439, 1683, 1495, 1407, $700 \mathrm{~cm}^{-1}$; HRMS (ESI ${ }^{+}$) calculated for $\mathrm{C}_{18} \mathrm{H}_{25} \mathrm{~N}_{2} \mathrm{O}_{3} \mathrm{~S}[\mathrm{M}+\mathrm{H}] 349.1586$, found 349.1547 .

\subsubsection{Tert-butyl $\mathbf{N}$-\{[4-(azidomethyl)-5-methyl-1,3-thiazol-2-yl]methyl\}- $\boldsymbol{N}$-benzylcarbamate (20)} Alcohol 19 (1.90 g, $5.45 \mathrm{mmol})$ was added to an oven dried $50 \mathrm{~mL}$ round bottom flask with stir bar. The flask was sealed under nitrogen and anhydrous DCM $(30 \mathrm{~mL})$ was added followed by mesyl chloride $(0.63 \mathrm{~mL}, 8.18 \mathrm{mmol})$ and triethylamine $(1.14 \mathrm{~mL}, 8.18 \mathrm{mmol})$. The reaction was warmed to $30^{\circ} \mathrm{C}$ and stirred for $12 \mathrm{~h}$. The DCM was removed via rotary evaporator, and the crude oil was taken up into anhydrous DMF ( $30 \mathrm{~mL}$ ). Sodium azide $(0.425 \mathrm{~g}, 6.54 \mathrm{mmol})$ was added in one portion and the reaction stirred for $6 \mathrm{~h}$. A sample aliquot was taken from the reaction, dissolved in $1 \mathrm{~mL} \mathrm{HPLC}$ grade MeCN, and analyzed with LC-MS to confirm reaction completion. The reaction was diluted with ether $(250 \mathrm{~mL})$ and water $(750 \mathrm{~mL})$, and the organic layer was separated and the aqueous layer extracted with ether $(2 \times 100 \mathrm{~mL})$. The combined organics were washed with brine, dried over sodium sulfate, filtered, and condensed to give a brown oil. The oil was dissolved with minimal DCM and purified by flash chromatography ( $25 \mathrm{~g} \mathrm{SiO}_{2}$ cartridge; 0-22\% EtOAc:hexanes gradient) to give the title compound as a yellow oil $(2.20 \mathrm{~g}, 51 \%)$. TLC $\mathrm{R}_{\mathrm{f}}=0.47$ (80:20 hexane:EtOAc); ${ }^{1} \mathrm{H} \mathrm{NMR}\left(300 \mathrm{MHz}, \mathrm{CDCl}_{3}\right) \delta=1.48$ $(\mathrm{s}, 9 \mathrm{H}), 2.43(\mathrm{~s}, 3 \mathrm{H}), 4.33(\mathrm{~s}, 2 \mathrm{H}), 4.41-4.67(\mathrm{~m}, 4 \mathrm{H}), 7.16-7.40(\mathrm{~m}, 5 \mathrm{H}) .{ }^{13} \mathrm{C}$ NMR is complicated due to rotamers. ${ }^{13} \mathrm{C} \mathrm{NMR}\left(75 \mathrm{MHz}, \mathrm{CDCl}_{3}\right) \delta=11.5,28.6,47.6,47.9,50.0,50.7,77.5,81.1,127.7,127.9,128.5,128.8$, 132.3, 132.7, 137.6, 137.7, 145.8, 155.3, 155.7, 165.1, 165.5; IR (film) 2977, 2094, 1690, 1241, $698 \mathrm{~cm}^{-1}$; HRMS $\left(\mathrm{ESI}^{+}\right.$) calculated for $\mathrm{C}_{18} \mathrm{H}_{24} \mathrm{~N}_{5} \mathrm{O}_{2} \mathrm{~S}[\mathrm{M}+\mathrm{H}] 374.1651$, found 374.1613.

\subsubsection{Tert-butyl N-\{[4-(aminomethyl)-5-methyl-1,3-thiazol-2-yl]methyl\}-N-benzylcarbamate (21)} Azide 20 (1.10 g, $2.95 \mathrm{mmol}$ ) was added to a $250 \mathrm{~mL}$ pressure flask with stir bar followed by methanol $(70 \mathrm{~mL})$. The flask was purged with argon, then $10 \% \mathrm{Pd} / \mathrm{C}(0.470 \mathrm{~g}, 0.442 \mathrm{mmol})$ was added. The reaction flask was attached to a Parr hydrogenator, evacuated, and backfilled with hydrogen to 2 atm $\times 3$. The reaction was stirred vigorously under $2 \mathrm{~atm}$ of hydrogen for $3 \mathrm{~h}$. A sample aliquot was taken from the reaction, dissolved in $1 \mathrm{~mL}$ HPLC grade MeCN, and analyzed with LC-MS to confirm reaction completion. The reaction mixture was passed through a pad of Celite, then concentrated to afford the title compound as a yellow oil $(0.955 \mathrm{~g}, 93 \%)$. The crude product was used directly without further purification. TLC $R_{f}=0.39$ (80:20 hexane:EtOAc); ${ }^{1} \mathrm{H} \mathrm{NMR}(300 \mathrm{MHz}$, $\left.\mathrm{CDCl}_{3}\right) \delta=1.51(\mathrm{~s}, 9 \mathrm{H}), 1.78$ (br. s. $\left.2 \mathrm{H}\right), 2.37(\mathrm{~s}, 3 \mathrm{H}), 3.78(\mathrm{~s}, 2 \mathrm{H}), 4.38-4.67(\mathrm{~m}, 4 \mathrm{H}), 7.14-7.39(\mathrm{~m}, 5 \mathrm{H}) ;{ }^{13} \mathrm{C}$ $\operatorname{NMR}\left(75 \mathrm{MHz}, \mathrm{CDCl}_{3}\right) \delta=11.2,28.6,39.5,47.9,50.0,50.1,50.8,80.9,127.6,127.7,128.4,128.7,137.7,137.8$, 151.8, 155.4, 155.7, 164.79; IR (film) 3054, 2976, 1691, 1452, 1117, $692 \mathrm{~cm}^{-1}$; HRMS (ESI ${ }^{+}$) calculated for $\mathrm{C}_{18} \mathrm{H}_{25} \mathrm{~N}_{3} \mathrm{O}_{2} \mathrm{~S}[\mathrm{M}+\mathrm{H}]$ 348.1746, found 348.1701.

\subsection{8. (\{2-[(Benzylamino)methyl]-5-methyl-1,3-thiazol-4-yl\}methyl)[(quinolin-8-yl)methyl]amine (22a)} Amine 21 (0.200 g, $0.576 \mathrm{mmol})$ was added to an oven dried $20 \mathrm{~mL}$ vial with stir bar followed by glacial acetic acid $(4.5 \mathrm{~mL})$. Next, quinoline-8-carbaldehyde $(0.105 \mathrm{~g}, 0.633 \mathrm{mmol})$ and sodium triacetoxyborohydride $(0.146 \mathrm{~g}$, $0.691 \mathrm{mmol}$ ) were added. The vial was purged with nitrogen and the reaction was stirred for $16 \mathrm{~h}$. A sample aliquot was taken from the reaction, dissolved in $1 \mathrm{~mL} \mathrm{HPLC}$ grade MeCN, and analyzed with LC-MS to confirm reaction completion. $1.0 \mathrm{~N}$ aq. $\mathrm{NaOH}$ was added until the $\mathrm{pH}$ was greater than 12 . The aqueous solution was saturated with $\mathrm{NaCl}$ and extracted with EtOAc $(3 \times 50 \mathrm{~mL})$. The combined organic layers were washed with brine, dried over sodium sulfate and condensed to give a dark red/brown oil. The oil was dissolved with DCM (10 mL) and Amberlyst 15 ion exchange resin $(2 \mathrm{~g})$ was added. The crude was stirred with the resin for $12 \mathrm{~h}$. A sample 
aliquot was taken from the reaction, dissolved in $1 \mathrm{~mL} \mathrm{HPLC}$ grade MeCN, and analyzed with LC-MS to confirm reaction the product had bound completely to the resin. The resin was filtered and washed with EtOAc (50 $\mathrm{mL}$ ). The washed resin was placed in a $50 \mathrm{~mL}$ round bottom flask with $3.5 \mathrm{~N}$ ammonia in methanol ( $30 \mathrm{~mL}$ ) and stirred for $3 \mathrm{~h}$. The resin was filtered and washed with $3.5 \mathrm{~N}$ ammonia in $\mathrm{MeOH}$ until no further material eluted, as detected by TLC. The combined washes were condensed to give a brown oil, which was dissolved with minimal DCM and purified by flash chromatography ( $5 \mathrm{~g} \mathrm{SiO}_{2} ; 0-12 \% 0.5 \mathrm{~N} \mathrm{NH}_{4}$ in $\left.\mathrm{MeOH}: \mathrm{DCM}\right)$ to give the title compound as a dark red oil (168 mg, 75\%). TLC Rf $=0.73$ (90:10 MeOH:DCM); $\left.{ }^{1} \mathrm{H} \mathrm{NMR} \mathrm{(400} \mathrm{MHz,} \mathrm{CDCl}_{3}\right) \delta=2.41$ $(\mathrm{s}, 3 \mathrm{H}), 3.84(\mathrm{~s}, 2 \mathrm{H}), 3.94(\mathrm{~s}, 2 \mathrm{H}), 4.02(\mathrm{~s}, 2 \mathrm{H}), 4.60(\mathrm{~s}, 2 \mathrm{H}), 7.25-7.36(\mathrm{~m}, 5 \mathrm{H}), 7.41(\mathrm{dd}, J=8.2,4.3 \mathrm{~Hz}, 1 \mathrm{H})$, $7.51(\mathrm{dd}, J=8.2,7.0 \mathrm{~Hz}, 1 \mathrm{H}), 7.76(\mathrm{dd}, J=19.4,7.6 \mathrm{~Hz}, 2 \mathrm{H}), 8.10-8.22(\mathrm{~m}, 1 \mathrm{H}), 8.78-8.90(\mathrm{~m}, 1 \mathrm{H}) ;{ }^{13} \mathrm{C}$ NMR $\left(75 \mathrm{MHz} \mathrm{CDCl}_{3}\right) \delta=11.5,46.7,50.4,50.6,53.4,121.3,126.5,127.3,127.5,128.4,128.6,128.7,129.1,129.4$, 136.6, 137.3, 140.0, 147.0, 149.5, 149.7, 167.7; IR (film) 3304, 2921, 1498, 1452, 792, $699 \mathrm{~cm}^{-1}$; HRMS (ESI+) calculated for $\mathrm{C}_{23} \mathrm{H}_{25} \mathrm{~N}_{4} \mathrm{~S}[\mathrm{M}+\mathrm{H}] 389.1800$, found 389.1759 .

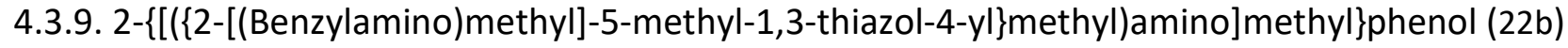
Amine 21 ( $0.150 \mathrm{~g}, 0.432 \mathrm{mmol}$ ) was added to an oven dried $100 \mathrm{~mL}$ round bottom flask with stir bar followed by anhydrous THF (35 mL). Next, salicylaldehyde $(0.063 \mathrm{~g}, 0.52 \mathrm{mmol})$ and sodium triacetoxyborohydride $(0.137 \mathrm{~g}, 0.648 \mathrm{mmol})$ were added. The vial was sealed under nitrogen and stirred for $16 \mathrm{~h}$. A sample aliquot was taken from the reaction, dissolved in $1 \mathrm{~mL} \mathrm{HPLC}$ grade MeCN, and analyzed with LCMS to confirm reaction completion. The reaction was washed with saturated ammonium chloride and the aqueous layer extracted with EtOAc $(2 \times 20 \mathrm{~mL})$. The combined organic layers were washed with brine, dried over sodium sulfate and condensed to give a yellow oil. The oil was dissolved with $\mathrm{DCM}(10 \mathrm{~mL})$ and Amberlyst ${ }^{\circ} 15$ ion exchange resin $(2 \mathrm{~g})$ was added. The crude was stirred with the resin for $12 \mathrm{~h}$. A sample aliquot was taken from the reaction, dissolved in $1 \mathrm{~mL} \mathrm{HPLC}$ grade MeCN, and analyzed with LC-MS to confirm the product had bound completely to the resin. After stirring the resin was filtered and washed with EtOAc before being placed in a $50 \mathrm{~mL}$ round bottom flask with $3.5 \mathrm{~N}$ ammonia in methanol and stirred for $3 \mathrm{~h}$. The resin washed with $3.5 \mathrm{~N}$ ammonia in $\mathrm{MeOH}$ until no further material could be seen coming off the resin by TLC. Combined washes were condensed to give a yellow oil. The compound was purified by flash chromatography (12 g C18 cartridge; $15-95 \% \mathrm{MeOH}: \mathrm{H}_{2} \mathrm{O}$ gradient) to afford the title compound as a pale yellow oil (70 mg, 45\%). TLC $R_{f}=0.53$ (90:10 DCM:MeOH); ${ }^{1} \mathrm{H}$ $\operatorname{NMR}\left(400 \mathrm{MHz}, \mathrm{CDCl}_{3} \delta=2.30(\mathrm{~s}, 3 \mathrm{H}), 3.76(\mathrm{~s}, 2 \mathrm{H}), 3.87(\mathrm{~s}, 2 \mathrm{H}), 3.94(\mathrm{~s}, 2 \mathrm{H}), 4.03(\mathrm{~s}, 2 \mathrm{H}), 6.77(\mathrm{t}, J=1.0 \mathrm{~Hz}\right.$, $1 \mathrm{H}), 6.84(\mathrm{~d}, J=8.2 \mathrm{~Hz}, 1 \mathrm{H}), 6.95(\mathrm{~d}, J=7.4 \mathrm{~Hz}, 1 \mathrm{H}), 7.17(\mathrm{t}, J=7.6 \mathrm{~Hz}, 1 \mathrm{H}), 7.22-7.30(\mathrm{~m}, 1 \mathrm{H}), 7.30-7.41(\mathrm{~m}$, $4 \mathrm{H}) ;{ }^{13} \mathrm{C}$ NMR $\left(101 \mathrm{MHz}, \mathrm{CDCl}_{3}\right) \delta=11.1,44.9,50.2,51.4,53.2,116.4,119.0,122.2,127.2,128.2,128.5,128.6$, 128.7, 129.5, 139.7, 148.3, 158.3, 168.10; IR (film) 3322, 2973, 2921, 1455, 1256, 1044, 754, $657 \mathrm{~cm}^{-1}$; HRMS $\left(\mathrm{ESI}^{+}\right.$) calculated for $\mathrm{C}_{20} \mathrm{H}_{24} \mathrm{~N}_{3} \mathrm{OS}[\mathrm{M}+\mathrm{H}] 354.1640$, found 354.1600 .

\subsubsection{2-\{[(\{2-[(Benzylamino)methyl]-5-methyl-1,3-thiazol-4-yl\}methyl)amino]methyl\}-4-chlorophenol}

\section{(22c)}

Prepared as described for 22b. Purified by flash chromatography (5 g SiO ${ }_{2}$ cartridge; 0-12\% $0.5 \mathrm{~N} \mathrm{NH}_{4}$ in $\mathrm{MeOH}: \mathrm{DCM}$ gradient) then (12 g C18 cartridge; $15-95 \% \mathrm{MeOH}: \mathrm{H}_{2} \mathrm{O}$ gradient) to afford the title compound as a pale yellow oil (56 mg, 33\%). TLC $R_{f}=0.50$ (90:10 DCM: MeOH); $\left.{ }^{1} \mathrm{H} \mathrm{NMR} \mathrm{(400} \mathrm{MHz,} \mathrm{CDCl}\right) \delta=2.30(\mathrm{~s}, 3 \mathrm{H}), 3.75$ $(\mathrm{s}, 2 \mathrm{H}), 3.88(\mathrm{~s}, 2 \mathrm{H}), 3.92(\mathrm{~s}, 2 \mathrm{H}), 4.04(\mathrm{~s}, 2 \mathrm{H}), 6.68-6.80(\mathrm{~m}, 1 \mathrm{H}), 6.81-6.92(\mathrm{~m}, 2 \mathrm{H}), 7.18-7.43(\mathrm{~m}, 5 \mathrm{H}) ;{ }^{13} \mathrm{C}$ $\operatorname{NMR}\left(75 \mathrm{MHz}, \mathrm{CDCl}_{3}\right) \delta=11.3,45.0,50.4,51.1,53.5,117.0,119.3,120.9,127.5,128.4,128.7,123.0,129.8$, 134.2, 139.8, 148.2, 159.5, 168.7; IR (film) 2952, 2865, 1479, 1236, $698 \mathrm{~cm}^{-1}$; HRMS (ESI ${ }^{+}$) calculated for $\mathrm{C}_{20} \mathrm{H}_{23} \mathrm{ClN}_{3} \mathrm{OS}[\mathrm{M}+\mathrm{H}] 388.1250$, found 388.1241 .

\subsubsection{2-\{[(\{2-[(Benzylamino)methyl]-5-methyl-1,3-thiazol-4-yl\}methyl)amino]methyl\}-4,6-di-tert-} butylphenol (22d)

Prepared as described for 22b. Purified by flash chromatography (12 g C18 cartridge; 25-95\% MeOH: $\mathrm{H}_{2} \mathrm{O}$ gradient) to afford the desired product as a light brown oil (94 mg, 47\%). TLC $R_{f}=0.66$ (90:10 DCM:MeOH); ${ }^{1} \mathrm{H}$ $\operatorname{NMR}\left(400 \mathrm{MHz}, \mathrm{CDCl}_{3}\right) \delta=1.27(\mathrm{~s}, 9 \mathrm{H}), 1.42(\mathrm{~s}, 9 \mathrm{H}), 2.31(\mathrm{~s}, 3 \mathrm{H}), 3.76(\mathrm{~s}, 2 \mathrm{H}), 3.88(\mathrm{~s}, 2 \mathrm{H}), 3.92(\mathrm{~s}, 2 \mathrm{H}), 4.03(\mathrm{~s}$, 
$2 \mathrm{H}), 6.81(\mathrm{~d}, J=2.4 \mathrm{~Hz}, 1 \mathrm{H}), 7.22(\mathrm{~d}, J=2.4 \mathrm{~Hz}, 1 \mathrm{H}), 7.23-7.39(\mathrm{~m}, 5 \mathrm{H}) ;{ }^{13} \mathrm{C} \mathrm{NMR}\left(101 \mathrm{MHz}, \mathrm{CDCl}_{3}\right) \delta=11.1$, 30.0, 31.7, 34.1, 34.9, 44.9, 50.2, 52.3, 53.2, 121.5, 122.9, 123.5, 127.2, 128.2, 128.5, 129.4, 135.8, 139.6, 140.3, 148.5, 154.7, 168.10; IR (film) 2920, 2843, 1604, 1488, 903, $699 \mathrm{~cm}^{-1}$; HRMS $\left(\mathrm{ESI}^{+}\right.$) calculated for $\mathrm{C}_{28} \mathrm{H}_{40} \mathrm{~N}_{3} \mathrm{OS}$ $[\mathrm{M}+\mathrm{H}]$ 466.2892, found 466.2863 .

\subsubsection{Tert-butyl 2-\{[(2S,3R)-3-hydroxy-1-methoxy-1-oxobutan-2-yl]carbamoyl\}pyrrolidine-1- carboxylate (23)}

$\mathrm{N}$-Boc-L-proline (14) $(5.38 \mathrm{~g}, 24.5 \mathrm{mmol})$ and L-threonine methyl ester, $\mathrm{HCl}$ salt (13) $(4.16 \mathrm{~g}, 24.5 \mathrm{mmol})$ were added to a $1.0 \mathrm{~L}$ round bottom flask with stir bar containing DCM $(400 \mathrm{~mL})$. HOBt $(4.13 \mathrm{~g}, 27.0 \mathrm{mmol})$ was added followed by TEA $(8.60 \mathrm{~mL}, 61.7 \mathrm{mmol})$ and EDC HCl $(5.17 \mathrm{~g}, 27.0 \mathrm{mmol})$. The reaction was stirred for $20 \mathrm{~h}$. A sample aliquot was taken from the reaction, dissolved in $1 \mathrm{~mL}$ HPLC grade MeCN, and analyzed with LC-MS to confirm reaction completion. The reaction was washed with half saturated aq. sodium bicarbonate $(2 \times 200 \mathrm{~mL})$ and $0.2 \mathrm{~N} \mathrm{HCl}(2 \times 200 \mathrm{~mL})$. The combined aqueous washes were extracted with DCM $(2 \times 100 \mathrm{~mL})$. The combined organics were washed with brine, dried over sodium sulfate, filtered, and condensed to give the title compound as a colorless oil $(5.91 \mathrm{~g}, 73 \%)$. The crude product was pushed forward without further purification. This compound has been previously reported and characterized (CAS\# 80897-23-0). ${ }^{1} \mathrm{H}$ NMR (300 MHz, $\left.\mathrm{CDCl}_{3}\right) \delta=1.19(\mathrm{~d}, J=6.4 \mathrm{~Hz}, 3 \mathrm{H}), 1.47(\mathrm{~s}, 9 \mathrm{H}), 1.80-2.35(\mathrm{~m}, 4 \mathrm{H}), 3.39-3.48(\mathrm{~m}, 2 \mathrm{H}), 3.77(\mathrm{~d}, J=1.7 \mathrm{~Hz}, 3 \mathrm{H})$, $4.26-4.36(\mathrm{~m}, 2 \mathrm{H}), 4.58(\mathrm{dd}, J=9.0,2.6 \mathrm{~Hz}, 1 \mathrm{H})$.

\subsubsection{Tert-butyl 2-\{[(2S)-1-methoxy-1,3-dioxobutan-2-yl]carbamoyl\}pyrrolidine-1-carboxylate (24)} Alcohol 23 (5.91 g, $17.9 \mathrm{mmol}$ ) was added to a $1 \mathrm{~L}$ round bottom flask with stir bar followed by DCM ( $300 \mathrm{~mL}$ ) and Dess-Martin periodinane $(8.35 \mathrm{~g}, 19.7 \mathrm{mmol})$. The flask was sealed with a septum and flushed with nitrogen. The reaction was stirred for $3 \mathrm{~h}$ before water $(0.322 \mathrm{~mL}, 17.9 \mathrm{mmol})$ was added and the reaction stirred for another $3 \mathrm{~h}$. A sample aliquot was taken from the reaction, dissolved in $1 \mathrm{~mL} \mathrm{HPLC}$ grade MeCN, and analyzed with LC-MS to confirm reaction completion. The reaction was poured on to a $10 \%$ sodium thiosulfate solution $(400 \mathrm{~mL})$ and stirred for $45 \mathrm{~min}$ until both layers turned clear. The organic layer was separated, washed with saturated aq. sodium bicarbonate $(2 \times 100 \mathrm{~mL})$ and brine, then dried over sodium sulfate, filtered, and condensed to give a yellow oil. The crude was purified by flash chromatography ( $100 \mathrm{~g} \mathrm{SiO}_{2}$ cartridge; $0-80 \%$ EtOAc/hexanes gradient) to yield the title compound as a yellow oil $(4.60 \mathrm{~g}, 78 \%)$. This compound has been previously reported and characterized (CAS\# 1027049-00-8).

\subsubsection{Methyl 2-\{1-[(tert-butoxy)carbonyl]pyrrolidin-2-yl\}-5-methyl-1,3-thiazole-4-carboxylate (25)} Ketone 24 (4.59 g, $14.0 \mathrm{mmol}$ ) was added to a $250 \mathrm{~mL}$ round bottom flask with stir bar followed by anhydrous THF (150 mL). The headspace was purged with nitrogen, then Lawesson's Reagent ( $8.46 \mathrm{~g}, 20.9 \mathrm{mmol})$ was added. The flask was fitted with a reflux condenser and the apparatus sealed with a septum and purged with nitrogen for $15 \mathrm{~min}$, before being heated to reflux for $18 \mathrm{~h}$. A sample aliquot was taken from the reaction, dissolved in $1 \mathrm{~mL} \mathrm{HPLC}$ grade MeCN, and analyzed with LC-MS to confirm reaction completion. The reaction was condensed to an oil, then dissolved in EtOAc $(250 \mathrm{~mL})$ and washed with saturated aq. sodium bicarbonate $(2 \times 250 \mathrm{~mL})$. The aqueous washes were extracted with EtOAc $(100 \mathrm{~mL})$, and the combined organics were washed with brine, dried over sodium sulfate, filtered, and condensed to give a red oil. The oil was adsorbed onto $\mathrm{SiO}_{2}(25 \mathrm{~g})$, then purified by flash chromatography (100 g SiO 2 cartridge; $0-40 \% \mathrm{EtOAc/hexanes} \mathrm{gradient)} \mathrm{to}$ yield the title compound as an orange oil $(3.46 \mathrm{~g}, 76 \%)$. This compound has been previously reported and characterized (CAS\# 838853-22-8): ${ }^{1} \mathrm{H}$ NMR $\left(300 \mathrm{MHz}, \mathrm{CDCl}_{3}\right) \delta=1.30-1.55(\mathrm{~m}, 9 \mathrm{H}), 1.84-2.00(\mathrm{~m}, 2 \mathrm{H}), 2.12-$ $2.45(\mathrm{~m}, 2 \mathrm{H}), 3.37-3.65(\mathrm{~m}, 2 \mathrm{H}), 3.93(\mathrm{~s}, 3 \mathrm{H}), 5.15(\mathrm{~d}, \mathrm{~J}=13.8 \mathrm{~Hz}, 1 \mathrm{H})$.

\subsubsection{Tert-butyl 2-[4-(hydroxymethyl)-5-methyl-1,3-thiazol-2-yl]pyrrolidine-1-carboxylate (26)} Ester 25 ( $3.43 \mathrm{~g}, 10.5 \mathrm{mmol}$ ) was added to an oven dried $100 \mathrm{~mL}$ round bottom flask followed by sodium triacetoxyborohydride $(0.112 \mathrm{~g}, 0.525 \mathrm{mmol})$, and sodium borohydride $(0.898 \mathrm{~g}, 23.1 \mathrm{mmol})$. The flask was fitted with a septum and the headspace purged with nitrogen before anhydrous THF ( $30 \mathrm{~mL})$ was added via cannula. 
The reaction stirred for $5 \mathrm{~min}$ then anhydrous methanol $(1.70 \mathrm{~mL}, 42.0 \mathrm{mmol}$ ) was added via syringe over $15 \mathrm{~min}$. The reaction was heated to $35^{\circ} \mathrm{C}$ for $16 \mathrm{~h}$. A sample aliquot was taken from the reaction, dissolved in $1 \mathrm{~mL} \mathrm{HPLC}$ grade MeCN, and analyzed with LC-MS to confirm reaction completion. The reaction was diluted with EtOAc $(30 \mathrm{~mL})$ and quenched with saturated aq. ammonium chloride. The layers were separated and the aqueous layer was extracted with $10 \% \mathrm{MeOH}$ in $\mathrm{DCM}(3 \times 50 \mathrm{~mL})$. The combined organic layers were washed with brine and condensed to give a thick yellow oil $(2.65 \mathrm{~g}, 85 \%)$. The crude material was moved forward without purification. [a]D25 -78.36 (0.573, DCM); TLC Rf: 0.57 (90:10 DCM:MeOH); ${ }^{1} \mathrm{H} \mathrm{NMR} \mathrm{(300} \mathrm{MHz,}$ $\left.\mathrm{CDCl}_{3}\right) \delta=1.34-1.47(\mathrm{~m}, 9 \mathrm{H}), 1.89-1.94(\mathrm{~m}, 2 \mathrm{H}), 2.17-2.28(\mathrm{~m}, 1 \mathrm{H}), 2.37-2.40(\mathrm{~m}, 2 \mathrm{H}), 3.39-3.56(\mathrm{~m}, 2 \mathrm{H}), 4.62$ $(\mathrm{s}, 3 \mathrm{H}), 5.03-5.15(\mathrm{~m}, 1 \mathrm{H}) ;{ }^{13} \mathrm{C}$ NMR is complicated due to rotamers. ${ }^{13} \mathrm{C} \mathrm{NMR}\left(75 \mathrm{MHz}, \mathrm{CDCl}_{3}\right) \delta=11.1,23.2$, 24.0, 28.4, 28.5, 32.9, 34.1, 46.6, 47.0, 58.1, 58.9, 59.4, 80.2, 128.5, 128.7, 150.7, 150.8, 154.4, 154.8, 171.5, 172.35; IR (film) 3377, 2975, 1698, 1388, 1366, 1165, $770 \mathrm{~cm}^{-1}$; HRMS (ESI ) calcd for $\mathrm{C}_{14} \mathrm{H}_{22} \mathrm{~N}_{2} \mathrm{O}_{3} \mathrm{~S}$ $[\mathrm{M}+\mathrm{H}]^{+}$299.1424, found 299.1405.

\subsubsection{Tert-butyl 2-[4-(azidomethyl)-5-methyl-1,3-thiazol-2-yl]pyrrolidine-1-carboxylate (27)}

Alcohol 26 ( $2.12 \mathrm{~g}, 7.11 \mathrm{mmol}$ ) was added to an oven dried $250 \mathrm{~mL}$ round bottom flask. The flask was purged with nitrogen and anhydrous DCM $(50 \mathrm{~mL})$ was added followed by mesyl chloride $(0.660 \mathrm{~mL}, 8.53 \mathrm{mmol})$ and triethylamine $(1.12 \mathrm{~mL}, 8.61 \mathrm{mmol})$. The reaction was stirred at room temperature for $24 \mathrm{~h}$. A sample aliquot was taken from the reaction, dissolved in $1 \mathrm{~mL} \mathrm{HPLC}$ grade MeCN, and analyzed with LC-MS to confirm reaction completion. The DCM was evaporated and the crude oil dissolved with anhydrous DMF $(50 \mathrm{~mL})$. Sodium azide $(0.544 \mathrm{~g}, 8.53 \mathrm{mmol})$ was added in one portion and the reaction stirred for $16 \mathrm{~h}$. The reaction was diluted with ether $(250 \mathrm{~mL})$ and washed with water $(3 \times 250 \mathrm{~mL})$. The aqueous layers were extracted with ether $(2 \times 100 \mathrm{~mL})$. The combined organics were washed with brine, dried over sodium sulfate, filtered, and condensed to give an orange oil. The oil was dissolved with minimal DCM and purified by flash chromatography $\left(25 \mathrm{~g} \mathrm{SiO}_{2}\right.$ cartridge; 0-20\% EtOAc:hexanes gradient) to give the title compound as a yellow oil (1.73 g, 75\%). [a]D25 -86.52 (0.620, $\mathrm{DCM}) ; \mathrm{TLC} \mathrm{R}_{\mathrm{f}}=0.40$ (80:20 hexane:EtOAc); ${ }^{1} \mathrm{H}$ NMR (300 MHz, CDCl $) \delta=1.36-1.48(\mathrm{~m}, 9 \mathrm{H}), 1.92-1.94(\mathrm{~m}, 2 \mathrm{H})$, 2.21-2.26 (m, 2H), $2.42(\mathrm{~s}, 3 \mathrm{H}), 3.44-3.55(\mathrm{~m}, 2 \mathrm{H}), 4.33(\mathrm{~s}, 2 \mathrm{H}), 5.03-5.12(\mathrm{~m}, 1 \mathrm{H}) ;{ }^{13} \mathrm{C}$ NMR is complicated due to rotamers. ${ }^{13} \mathrm{C}$ NMR $\left(100 \mathrm{MHz}, \mathrm{CDCl}_{3}\right) \delta=11.2,23.1,23.9,28.3,28.4,32.5,33.8,46.5,46.9,47.5,58.8,59.3$, 80.0, 80.1, 130.8, 131.0, 145.7, 146.0, 154.2, 154.6, 171.2, 172.3; IR (film) 2976, 2093, 1695, 1384, 1166, 1113, $769 \mathrm{~cm}^{-1}$; HRMS $\left(E S I^{+}\right)$calcd for $\mathrm{C}_{14} \mathrm{H}_{21} \mathrm{~N}_{5} \mathrm{O}_{2} \mathrm{~S}[\mathrm{M}+\mathrm{H}]^{+} 324.1489$, found 324.1457 .

\subsubsection{Tert-butyl 2-[4-(aminomethyl)-5-methyl-1,3-thiazol-2-yl]pyrrolidine-1-carboxylate (28)}

Azide 27 ( $1.63 \mathrm{~g}, 5.05 \mathrm{mmol}$ ) was added to a $250 \mathrm{~mL}$ pressure flask followed by methanol $(50 \mathrm{~mL})$. The flask was purged with argon then $10 \% \mathrm{Pd} / \mathrm{C}(0.537 \mathrm{~g}, 0.505 \mathrm{mmol})$ was added. The reaction flask was attached to a Parr hydrogenator, evacuated, and backfilled with hydrogen $\times 3$. The reaction was stirred vigorously under 3 bar of hydrogen for $16 \mathrm{~h}$. A sample aliquot was taken from the reaction, dissolved in $1 \mathrm{~mL} \mathrm{HPLC}$ grade MeCN, and analyzed with LCMS to confirm reaction completion. The reaction mixture was passed through a pad of Celite, then concentrated to afford a colorless oil $(1.30 \mathrm{~g}, 87 \%)$. The crude product was used directly without further purification. [a]D25 -83.71 (0.653, DCM); TLC Rf: 0.39 (90:10 DCM:MeOH); ${ }^{1} \mathrm{H} \mathrm{NMR}\left(300 \mathrm{MHz}, \mathrm{CDCl}_{3}\right) \delta=1.35-$ $1.49(\mathrm{~m}, 9 \mathrm{H}), 1.67$ (br. s. 2H), 1.92-1.95 (m, 2H), 2.21-2.28 (m, 2H), $2.37(\mathrm{~s}, 3 \mathrm{H}), 3.39-3.57(\mathrm{~m}, 3 \mathrm{H}), 3.79(\mathrm{~s}, 2 \mathrm{H})$, 5.01-5.15 (m, $1 \mathrm{H}) ;{ }^{13} \mathrm{C}$ NMR is complicated due to rotamers. ${ }^{13} \mathrm{C} \mathrm{NMR}\left(100 \mathrm{MHz}, \mathrm{CDCl}_{3}\right) \delta=11.1,23.2,23.9,28.4$, 28.6, 32.9, 34.0, 39.8, 46.5, 47.0, 59.0, 59.5, 80.1, 126.5, 126.6, 152.5, 152.8, 154.4, 154.8, 171.1, 171.72; IR (film) 3356, 3301, 2974, 1694, 1385, 1164, 1113, $770 \mathrm{~cm}^{-1}$; HRMS (ESI') calcd for $\mathrm{C}_{14} \mathrm{H}_{23} \mathrm{~N}_{3} \mathrm{O}_{2} \mathrm{~S}[\mathrm{M}+\mathrm{H}]^{+} 298.1584$, found 298.1548 .

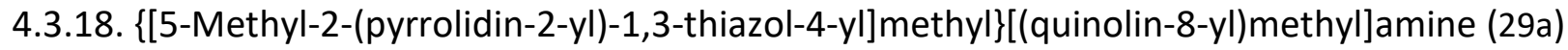

Amine 28 ( $0.200 \mathrm{~g}, 0.576 \mathrm{mmol})$ was added to an oven dried $25 \mathrm{~mL}$ vial with stir bar followed by glacial acetic acid $(5.0 \mathrm{~mL})$. Next, quinoline-8-carbaldehyde $(0.128 \mathrm{~g}, 0.777 \mathrm{mmol})$ and sodium triacetoxyborohydride $(0.180$, $0.847 \mathrm{mmol}$ ) were added. The vial was purged with nitrogen and allowed to stir for $16 \mathrm{~h}$. A sample aliquot was taken from the reaction, dissolved in $1 \mathrm{~mL}$ HPLC grade MeCN, and analyzed with LCMS to confirm reaction 
completion. The reaction was neutralized with saturated aq. sodium bicarbonate and brought to $\mathrm{pH}=9$. The aqueous solution was extracted with EtOAc $(2 \times 20 \mathrm{~mL})$. The combined organic layers were washed with brine, dried over sodium sulfate, filtered, and condensed to give a dark orange oil. The oil was dissolved with DCM $(50 \mathrm{~mL})$, and Amberlyst 15 ion exchange resin $(4 \mathrm{~g})$ was added. The crude was stirred with the resin for $16 \mathrm{~h}$. A sample aliquot was taken from the reaction, dissolved in $1 \mathrm{~mL}$ HPLC grade MeCN, and analyzed with LC-MS to confirm that the desired product had completely bound to the resin. The resin was filtered and washed with $\mathrm{DCM}(50 \mathrm{~mL})$ and $\mathrm{MeOH}(50 \mathrm{~mL})$. The washed resin was placed in a $50 \mathrm{~mL}$ round bottom flask with $3.5 \mathrm{~N}$ ammonia in methanol $(30 \mathrm{~mL})$ and was stirred for $16 \mathrm{~h}$. After $16 \mathrm{~h}$, the resin was filtered and washed with $3.5 \mathrm{~N}$ ammonia in $\mathrm{MeOH}$ until no further material was eluted, as detected by TLC. The combined washes were condensed to give a yellow oil. The crude was purified by flash chromatography $\left(5 \mathrm{~g} \mathrm{SiO}_{2} ; 0-27 \% 0.5 \mathrm{~N} \mathrm{NH}_{3}\right.$ in $\mathrm{MeOH}: \mathrm{DCM}$ ) to give the title compound as a pale yellow oil (75 mg, 32\%). [a]D25 -37.73 (0.273, DCM); TLC $\mathrm{R}_{\mathrm{f}}=0.16(90: 10 \mathrm{MeOH}: \mathrm{DCM}) ;{ }^{1} \mathrm{H}$ NMR $\left(400 \mathrm{MHz}, \mathrm{CDCl}_{3}\right) \delta=1.72-1.99(\mathrm{~m}, 3 \mathrm{H}), 2.18-2.29(\mathrm{~m}, 1 \mathrm{H}), 2.32(\mathrm{~s}, 3 \mathrm{H})$, 2.53 (br s, 2H), 3.01 (ddd, $J=10.0,7.6,6.5 \mathrm{~Hz}, 1 \mathrm{H}$ ), 3.10 (ddd, $J=10.0,7.2,5.3,1 \mathrm{H}$ ), $3.85(\mathrm{~s}, 2 \mathrm{H}), 4.39-4.49(\mathrm{~m}$, $3 \mathrm{H}), 7.40(\mathrm{dd}, J=8.3,4.2 \mathrm{~Hz}, 1 \mathrm{H}), 7.49(\mathrm{dd}, J=8.3,6.9 \mathrm{~Hz}, 1 \mathrm{H}), 7.67-7.75(\mathrm{~m}, 2 \mathrm{H}), 8.14(\mathrm{dd}, J=8.3,1.8 \mathrm{~Hz}, 1 \mathrm{H})$, $8.91(\mathrm{dd}, J=4.2,1.8 \mathrm{~Hz}, 1 \mathrm{H}) ;{ }^{13} \mathrm{C}$ NMR $\left(100 \mathrm{MHz}, \mathrm{CDCl}_{3}\right) \delta=11.3,25.6,33.9,47.0,50.4,49.9,121.0,126.4,127.0$, 127.9, 128.4, 128.9, 136.40, 138.4, 147.0, 149.5, 150.4, 173.7; IR (film) 3301, 2919, 1498, 1445, 828, $792 \mathrm{~cm}^{-1}$; HRMS $\left(\right.$ ESI $^{+}$) calcd for $\mathrm{C}_{19} \mathrm{H}_{22} \mathrm{~N}_{4} \mathrm{~S}[\mathrm{M}+\mathrm{H}]^{+} 339.1638$, found 339.1607 .

\subsubsection{2-[(\{[5-Methyl-2-(pyrrolidin-2-yl)-1,3-thiazol-4-yl]methyl\}amino)methyl]phenol (29b)}

Amine 28 ( $0.195 \mathrm{~g}, 0.655 \mathrm{mmol})$ was added to an oven dried $100 \mathrm{~mL}$ round bottom flask followed by anhydrous THF $(30 \mathrm{~mL})$. Next, salicylaldehyde $(0.088 \mathrm{~g}, 0.720 \mathrm{mmol})$ and sodium triacetoxyborohydride $(0.167 \mathrm{~g}$, $0.786 \mathrm{mmol}$ ) were added. The vial was purged with nitrogen and stirred for $16 \mathrm{~h}$. A sample aliquot was taken from the reaction, dissolved in $1 \mathrm{~mL} \mathrm{HPLC}$ grade MeCN, and analyzed with LC-MS to confirm reaction completion. Next, the reaction was quenched with saturated aq. ammonium chloride and basified with saturated aq. sodium bicarbonate. The aqueous layer was extracted with EtOAc $(2 \times 20 \mathrm{~mL})$ and the combined organic layers were washed with brine, dried over sodium sulfate, filtered, and condensed to give a yellow oil. The oil was dissolved with DCM $(50 \mathrm{~mL})$, and Amberlyst ${ }^{\circ} 15$ ion exchange resin $(4 \mathrm{~g})$ was added. The crude was stirred with the resin for $16 \mathrm{~h}$. A sample aliquot was taken from the reaction, dissolved in $1 \mathrm{~mL} \mathrm{HPLC}$ grade $\mathrm{MeCN}$, and analyzed with LC-MS to confirm that the desired product had completely bound to the resin. The resin was filtered and washed with $\mathrm{DCM}(50 \mathrm{~mL})$ and $\mathrm{MeOH}(50 \mathrm{~mL})$. The washed resin was placed in a $50 \mathrm{~mL}$ round bottom flask with $3.5 \mathrm{~N}$ ammonia in methanol $(30 \mathrm{~mL})$ and was stirred for $16 \mathrm{~h}$. After $16 \mathrm{~h}$, the resin was filtered and washed with $3.5 \mathrm{~N}$ ammonia in $\mathrm{MeOH}$ until no further material was eluted, as determined by TLC. The combined washes were condensed to give a brown oil. The compound was purified by flash chromatography (10 $\mathrm{g} \mathrm{SiO}_{2} ; 0-12 \% 0.5 \mathrm{~N} \mathrm{NH}_{3}$ in $\left.\mathrm{MeOH}: \mathrm{DCM}\right)$ to afford a colorless oil (119 mg, 60\%). [a]D25 45.04 (2.280, DCM); TLC Rf $=0.19$ (90:10 DCM:MeOH); ${ }^{1} \mathrm{H}$ NMR (400 MHz, $\left.\mathrm{CDCl}_{3}\right) \delta=1.74-1.98(\mathrm{~m}, 3 \mathrm{H}), 2.22-$ $2.26(\mathrm{~m}, 4 \mathrm{H}), 2.97-3.17(\mathrm{~m}, 2 \mathrm{H}), 3.74(\mathrm{~s}, 2 \mathrm{H}), 3.93(\mathrm{~s}, 2 \mathrm{H}), 4.45(\mathrm{dd}, J=8.0,5.4 \mathrm{~Hz}, 1 \mathrm{H}), 6.76(\mathrm{td}, J=7.4,1.2 \mathrm{~Hz}$, $1 \mathrm{H}), 6.83(\mathrm{dd}, J=8.1,1.1 \mathrm{~Hz}, 1 \mathrm{H}), 6.94(\mathrm{dd}, J=7.4,1.5 \mathrm{~Hz}, 1 \mathrm{H}), 7.16(\mathrm{td}, J=8.0,1.7 \mathrm{~Hz}, 1 \mathrm{H}) ;{ }^{13} \mathrm{C} \mathrm{NMR}(100 \mathrm{MHz}$, $\left.\mathrm{CDCl}_{3}\right) \delta=11.0,25.6,33.9,45.0,47.0,51.4,49.8,116.4,119.0,122.3,128.6,128.7,128.9,148.4,158.3,174.8 ; \mathrm{IR}$ (film) 3290, 2920, 1589, 1490, 1474, 1456, 1256, $754 \mathrm{~cm}^{-1}$; HRMS (ESI $)$ calcd for $\mathrm{C}_{16} \mathrm{H}_{21} \mathrm{~N}_{3} \mathrm{OS}[\mathrm{M}+\mathrm{H}]^{+} 304.1478$, found 304.1452 .

\subsubsection{4-Chloro-2-[(\{[5-methyl-2-(pyrrolidin-2-yl)-1,3-thiazol-4-yl]methyl\}amino)methyl]phenol (29c)}

Prepared as described for $29 \mathrm{~b}$. Compound purified by flash chromatography $\left(10 \mathrm{~g} \mathrm{SiO}_{2} ; 0-12 \% 0.5 \mathrm{~N} \mathrm{NH}_{4}\right.$ in $\mathrm{MeOH}: \mathrm{DCM}$ ) to afford the title compound as a yellow oil (101 mg, 43\%). [a]D25 -39.46 (0.147, DCM); TLC $\mathrm{R}_{\mathrm{f}}=0.33$ (90:10 DCM:MeOH); ${ }^{1} \mathrm{H}$ NMR $\left(400 \mathrm{MHz}, \mathrm{CDCl}_{3}\right) \delta=1.81-1.99(\mathrm{~m}, 3 \mathrm{H}), 2.21-2.27(\mathrm{~m}, 4 \mathrm{H}), 2.99-3.19(\mathrm{~m}$, 2H), $3.73(\mathrm{~s}, 2 \mathrm{H}), 3.90(\mathrm{~s}, 2 \mathrm{H}), 4.47(\mathrm{dd}, J=7.6,5.4 \mathrm{~Hz}, 1 \mathrm{H}), 5.52(\mathrm{br} \mathrm{s}, 2 \mathrm{H}), 6.73(\mathrm{dd}, J=8.0,2.0 \mathrm{~Hz}, 1 \mathrm{H}), 6.81-6.87$ $(\mathrm{m}, 2 \mathrm{H}) ;{ }^{13} \mathrm{C}$ NMR $\left(100 \mathrm{MHz}, \mathrm{CDCl}_{3}\right) \delta=11.1,25.5,33.9,44.8,46.9,50.8,59.7,116.7,119.0,120.8,129.2,129.4$, 133.9, 148.0, 159.2, 174.1; IR (film) 2923, 1585, 1447, 1237, 1081, $902 \mathrm{~cm}^{-1}$; HRMS (ESI ${ }^{+}$) calcd for $\mathrm{C}_{16} \mathrm{H}_{20} \mathrm{~N}_{3} \mathrm{OSCl}$ $[\mathrm{M}+\mathrm{H}]^{+} 338.1088$, found 338.1058 . 
Prepared as described for $29 \mathrm{~b}$. Compound purified by flash chromatography $\left(10 \mathrm{~g} \mathrm{SiO}_{2} ; 0-7 \% 0.5 \mathrm{~N} \mathrm{NH}_{4}\right.$ in $\mathrm{MeOH}: \mathrm{DCM}$ ) to afford the title compound as a colorless oil (91 mg, 48\%). [a]D25-30.41 (1.207, DCM); TLC $\mathrm{R}_{\mathrm{f}}=0.48$ (90:10 DCM:MeOH); ${ }^{1} \mathrm{H}$ NMR $\left(300 \mathrm{MHz}, \mathrm{CDCl}_{3}\right) \delta=1.28(\mathrm{~s}, 9 \mathrm{H}), 1.42(\mathrm{~s}, 9 \mathrm{H}), 1.90(\mathrm{~m}, 3 \mathrm{H}), 2.20-2.28(\mathrm{~m}$, $4 \mathrm{H}), 3.01-3.17(\mathrm{~m}, 2 \mathrm{H}), 3.75(\mathrm{~s}, 2 \mathrm{H}), 3.91(\mathrm{~s}, 2 \mathrm{H})), 4.46(\mathrm{dd}, J=7.7,5.4 \mathrm{~Hz}, 2 \mathrm{H}), 6.82(\mathrm{~d}, J=1.8 \mathrm{~Hz}, 1 \mathrm{H}), 7.22$ $(\mathrm{d}, J=1.8 \mathrm{~Hz}, 1 \mathrm{H}) ;{ }^{13} \mathrm{C} \mathrm{NMR}\left(75 \mathrm{MHz}, \mathrm{CDCl}_{3}\right) \delta=11.2,25.6,29.7,31.8,34.0,34.2,35.0,45.1,47.0,52.4,59.7$, 121.7, 123.0, 123.6, 128.9, 135.9, 140.4, 148.7, 154.8, 174.5; IR (film) 3276, 2951, 1480, 1485, 1443, 1236, 877, $820 \mathrm{~cm}^{-1}$; HRMS $\left(\mathrm{ESI}^{+}\right)$calcd for $\mathrm{C}_{24} \mathrm{H}_{37} \mathrm{~N}_{3} \mathrm{OS}[\mathrm{M}+\mathrm{H}]^{+} 416.2730$, found 416.2709 .

\subsection{General protocol for intramolecular carbocyclization screens}

The procedure used was adopted from the protocol reported by Michelet [28]. First, a stock solution was made by adding formyl alkyne $1 \mathrm{a}(200 \mathrm{mg}, 0.790 \mathrm{mmol})$ and cyclohexylamine $(0.018 \mathrm{~mL}, 0.16 \mathrm{mmol})$ to a $4 \mathrm{~mL}$ vial with stir bar containing DCE $(2.0 \mathrm{~mL})$. After $10 \mathrm{~min}, 0.2 \mathrm{~mL}$ of this solution which contained formyl alkyne 1a $(0.020 \mathrm{~g}, 0.079 \mathrm{mmol})$ and cyclohexylamine $(1.8 \mu \mathrm{L}, 0.016 \mathrm{mmol})$, was added to a $1.5 \mathrm{~mL} \mathrm{HPLC}$ vial, which contained a solution of the ligand $(0.012 \mathrm{mmol})$ and metal salt $(0.012 \mathrm{mmol})$ in DCE $(0.15 \mathrm{~mL})$. The vials were capped and shaken for $16 \mathrm{~h}$. The reaction mixtures were filtered through silica plugs in Pasteur pipets, eluted with EtOAc $(\sim 2 \mathrm{~mL})$, and condensed. Yields of $\mathbf{1 b}$ were measured by ${ }^{1} \mathrm{H} N M R$ in $\mathrm{CDCl}_{3}$ using pentachloroethane as an internal standard. Reactions using $\mathrm{Cu}(\mathrm{l})$ metal salts followed the same general procedure, however sample vials were set up in the glovebox and stirred on the benchtop.

\subsection{General procedure for intermolecular reaction screens}

First, alkyne and carbonyl stock solutions were made by mixing the alkyne $(0.65 \mathrm{mmol})$ with DCE $(0.75 \mathrm{~mL})$ in a $1.5 \mathrm{~mL} \mathrm{HPLC}$ vial. Carbonyl compounds $(0.155 \mathrm{mmol})$ were mixed with DCE $(0.6 \mathrm{~mL})$ in a $1.5 \mathrm{~mL} \mathrm{HPLC}$ vial. The vials were sealed and argon was bubbled through the solutions for $10 \mathrm{~min}$ before they were brought into the glovebox. In the glovebox, ligand $22 \mathrm{a}$ and $\left(\mathrm{CH}_{3} \mathrm{CN}\right)_{4} \mathrm{CuBF}_{4}$ stock solutions was made by weighing the metal salt $(0.035 \mathrm{~g}, 0.109 \mathrm{mmol})$ into a $20 \mathrm{~mL}$ scintillation vial, followed by addition of $22 \mathrm{a}(0.042 \mathrm{~g}, 0.109 \mathrm{mmol})$ as a solution in $10.5 \mathrm{~mL} \mathrm{DCE} .0 .5 \mathrm{~mL}$ of this stock solution containing $22 \mathrm{a}(2.0 \mathrm{mg}, 0.005 \mathrm{mmol})$ and $\left(\mathrm{CH}_{3} \mathrm{CN}\right)_{4} \mathrm{CuBF}_{4}(1.7 \mathrm{mg} 0.005 \mathrm{mmol})$ was added to separate $\mathrm{HPLC}$ vials before the alkyne $(0.130 \mathrm{mmol})$ was added as a stock solution $(0.15 \mathrm{~mL}$ to each vial), followed by the stock solution of carbonyl compound $(0.10 \mathrm{~mL}$, $0.026 \mathrm{mmol})$. If additives $(0.005 \mathrm{mmol}$ ) were used, they were added at this point as solutions in $0.1 \mathrm{~mL} \mathrm{DCE}$. The reaction vials were removed from the glovebox, sealed with parafilm, and heated in a sand bath at $50{ }^{\circ} \mathrm{C}$ without stirring for $16 \mathrm{~h}$. After heating, the samples were directly analyzed by GC-MS. GC-MS method (see General Information for further details): $50{ }^{\circ} \mathrm{C}-100{ }^{\circ} \mathrm{C}$ over $2 \mathrm{~min}$, then hold at $100{ }^{\circ} \mathrm{C}$ for $2 \mathrm{~min}$, ramp to $280{ }^{\circ} \mathrm{C}$ over $18 \mathrm{~min}$, then hold at $280^{\circ} \mathrm{C}$ for $8 \mathrm{~min} 2 \mu \mathrm{L}$ injection volume.

\subsection{General protocol for crystallizations of metal complexes}

In the glovebox, $\mathrm{Cu}(\mathrm{I})$ metal salts $(0.010 \mathrm{mmol})$ were weighed into an oven dried $1.5 \mathrm{~mL} \mathrm{HPLC}$ vial. The ligand $(0.010 \mathrm{mmol})$ was added to the metal salt as a solution in $\mathrm{CH}_{3} \mathrm{NO}_{2}(0.5 \mathrm{~mL})$. The vial caps were pierced with a needle and the vials were sealed in a Chemglass Airfree ${ }^{\circ}$ drying chamber. The chamber was removed from the glovebox and placed under vacuum $(0.1 \mathrm{~mm} \mathrm{Hg})$ for $12 \mathrm{~h}$ to remove the solvent. The dried samples were brought back into the glovebox where they were dissolved with $0.1 \mathrm{~mL} 1: 1 \mathrm{CH}_{3} \mathrm{NO}_{2}$ :benzene and placed in a shortened $5 \mathrm{~mm}$ NMR tube $(\sim 2.5 \mathrm{~cm}$ long), which was set inside of a $4 \mathrm{~mL}$ vial. Ether $(0.4 \mathrm{~mL})$ was added to the vial containing the sample tube, and the vials were tightly capped with septa, placed into the Chemglass Airfree drying chamber, and removed from the glovebox. The chamber sat in a dark cabinet for 3-7 days to allow crystals to form. Samples containing non-oxygen sensitive complexes were set up outside of the glovebox but followed the same general procedure. 


\subsection{Crystallographic data}

CCDC 1834245 and 1834246 (Fig. 3) and 1833343 (Fig. 4) contain the supplementary crystallographic data for this paper. These data can be obtained free of charge from the Cambridge Crystallographic Data Centre via https://www.ccdc.cam.ac.uk.

\subsection{Protocol for NMR binding studies with precatalyst}

Precatalyst 22a $(0.004 \mathrm{~g}, 0.010 \mathrm{mmol})$ was added to a $4 \mathrm{~mL}$ vial followed by $\mathrm{CD}_{3} \mathrm{NO}_{2}(0.8 \mathrm{~mL})$. The vial was sealed with a septum and the solution was purged with argon for $10 \mathrm{~min}$ before being brought into the glovebox. $\left(\mathrm{CH}_{3} \mathrm{CN}\right)_{4} \mathrm{CuBF}_{4}(0.003 \mathrm{~g}, 0.010 \mathrm{mmol})$ was weighed into a $1.5 \mathrm{~mL} \mathrm{HPLC}$ vial in the glovebox, and the ligand solution was transferred to this vial. After the solution became homogeneous, $0.4 \mathrm{~mL}$ was transferred to an NMR tube for analysis. To the remainder of the solution in the glovebox, phenylacetylene $(0.5 \mu \mathrm{L}, 0.005 \mathrm{mmol})$ was added via microsyringe. This solution was transferred to an NMR tube for analysis.

\section{Author contributions}

Conceived project: C.D. Designed catalysts: C.D., J.D.P., A.R.B. Performed Conia-ene studies: J.D.P. Performed NMR studies: J.D.P. Performed DFT calculations: J.D.P., E.G., C.D. Synthesized and characterized precatalysts: J.D.P., E.G., A.A., A.R.B. Screened reactions: J.D.P., E.G. Performed crystallization studies: J.D.P. Performed x-ray diffraction and data analysis: S.L. Wrote the manuscript: C.D., J.D.P.

\section{Notes}

An earlier version of this manuscript was submitted to the preprint server ChemRxiv: https://doi.org/10.26434/chemrxiv.6163430.v1.

\section{Acknowledgments}

We thank Dr. Sheng Cai for assistance with LC-MS and NMR instruments, Prof. Chae Yi for helpful comments, Shimadzu Inc. for a grant to support the purchase of the LC-MS used in these studies, Marquette University for startup funding, and the American Chemical Society Petroleum Research Fund (grant number 55732-DNI1) for support of this project. We also thank ChemAxon and ACD/Labs for use of their NMR prediction and processing software.

\section{Appendix A. Supplementary data}

The following is the supplementary data related to this article:

Figure S1 (Comparison of DFT calculations of $\mathrm{Cu}(\mathrm{l}) \mathrm{vs} \mathrm{Ag}(\mathrm{I})$ metals for bifunctional catalysis of $\mathrm{C}$ _ $\mathrm{C}$ formation with acetone and acetylene); Table S1 (DFT calculations for bifunctional catalysis of $\mathrm{C} \_\mathrm{C}$ bond formation with acetone and 1-butyne); Figure S2 (Representative DFT-optimized structures of alkyne complex (10) and adduct after $\mathrm{C} \_\mathrm{C}$ bond formation (11)); Figure S3 (NMR study of $\mathrm{Cu}(\mathrm{I})$ complex); ${ }^{1} \mathrm{H}$ and ${ }^{13} \mathrm{C}$ NMR spectra; representative Gaussian input files; Cartesian coordinates for select DFT-optimized structures.

Download Acrobat PDF file (4MB)Help with pdf files Multimedia component 1.

\section{Research data for this article}


Crystallographic data

Data associated with the article:

CCDC 1834246: Experimental Crystal Structure Determination

CCDC 1833343: Experimental Crystal Structure Determination

CCDC 1834245: Experimental Crystal Structure Determination

About research data

\section{References}

[1] B. List, R.A. Lerner, C.F. Barbas J. Am. Chem. Soc., 122 (2000), pp. 2395-2396

[2] R. Mahrwald Drug Discov. Today Technol., 10 (2013), pp. e29-e36

[3] A.E. Allen, D.W.C. MacMillan Chem. Sci., 3 (2012), p. 633

[4] Z. Du, Z. Shao Chem. Soc. Rev., 42 (2013), p. 1337

[5] Y. Deng, S. Kumar, H. Wang Chem. Commun., 50 (2014), p. 4272

[6] A. Gualandi, L. Mengozzi, C.M. Wilson, P.G. Cozzi Chem. Asian J., 9 (2014), pp. 984-995

[7] P.J. Walsh, M.C. Kozlowski Fundamentals of Asymmetric Catalysis University Science Books (2009)

[8] Y. Ito, M. Sawamura, T. Hayashi J. Am. Chem. Soc., 108 (1986), pp. 6405-6406

[9] Y. Hamashima, D. Sawada, M. Kanai, M. Shibasaki J. Am. Chem. Soc., 121 (1999), pp. 2641-2642

[10] S. France, M.H. Shah, A. Weatherwax, H. Wack, J.P. Roth, T.Lectka J. Am. Chem. Soc., 127 (2005), pp. 12061215

[11] D. Wiedenhoeft, A. Benoit, J. Porter, Y. Wu, R. Virdi, A. Shanaa, C. Dockendorff Synthesis, 48 (2016), pp. 2413-2422

[12] D.Wiedenhoeft, A.R. Benoit, Y. Wu, J.D. Porter, E. Meyle, T.H.W. Yeung, R. Huff, S.V. Lindeman, C. Dockendo rff Tetrahedron, 72 (2016), pp. 3905-3916

[13] J. Paradowska, M. Pasternak, B. Gut, B. Gryzło, J. Mlynarski J. Org. Chem., 77 (2012), pp. 173-187

[14] M. Pasternak, J. Paradowska, M. Rogozińska, J. Mlynarski Tetrahedron Lett., 51 (2010), pp. 4088-4090

[15] J. Paradowska, M. Stodulski, J. Mlynarski Adv. Synth. Catal., 349 (2007), pp. 1041-1046

[16] Z. Xu, P. Daka, H. Wang Chem. Commun. (2009), p. 6825

[17] Z. Xu, P. Daka, I. Budik, H. Wang, F.-Q. Bai, H.-X. Zhang Eur. J. Org. Chem., 2009 (2009), pp. 4581-4585

[18] P. Daka, Z. Xu, A. Alexa, H. Wang Chem. Commun., 47 (2011), pp. 224-226

[19] T. Pei, R.A. Widenhoefer J. Am. Chem. Soc., 123 (2001), pp. 11290-11291

[20] X. Wang, R.A. Widenhoefer Chem. Commun. (2004), pp. 660-661

[21] D. Hack, M. Blumel, P. Chauhan, A.R. Philipps, D. Enders Chem. Soc. Rev., 44 (2015), pp. 6059-6093

[22] J.T. Binder, B. Crone, T.T. Haug, H. Menz, S.F. Kirsch Org. Lett., 10 (2008), pp. 1025-1028

[23] T. Yang, A. Ferrali, L. Campbell, D. Dixon J. Chem. Commun. (2008), p. 2923

[24] K.L. Jensen, P.T. Franke, C. Arróniz, S. Kobbelgaard, K.A.Jørgensen Chem. Eur. J., 16 (2010), pp. 1750-1753

[25] Y.-P. Xiao, X.-Y. Liu, C.-M. Che Angew. Chem. Int. Ed., 50 (2011), pp. 4937-4941

[26] B. Montaignac, M.R. Vitale, V. Michelet, V. Ratovelomanana-Vidal Org. Lett., 12 (2010), pp. 2582-2585

[27] B. Montaignac, M.R. Vitale, V. Ratovelomanana-Vidal, V.Michelet J. Org. Chem., 75 (2010), pp. 8322-8325

[28] B. Montaignac, M.R. Vitale, V. Ratovelomanana-Vidal, V.Michelet Eur. J. Org. Chem., 2011 (2011), pp. 37233727

[29] B. Montaignac, C. Praveen, M.R. Vitale, V. Michelet, V.Ratovelomanana-Vidal Chem. Commun., 48 (2012), pp. $6559-6561$

[30] K. Endo, T. Hatakeyama, M. Nakamura, E. Nakamura J. Am. Chem. Soc., 129 (2007), pp. 5264-5271

[31] T. Fujimoto, K. Endo, H. Tsuji, M. Nakamura, E. Nakamura J. Am. Chem. Soc., 130 (2008), pp. 4492-4496

[32] F. Mo, G. Dong Science, 345 (2014), pp. 68-72

[33] Z. Wang, B.J. Reinus, G. Dong Chem. Commun., 50 (2014), p. 5230

[34] F. Mo, H.N. Lim, G. Dong J. Am. Chem. Soc., 137 (2015), pp. 15518-15527

[35] T. Ankner, C.C. Cosner, P. Helquist Chem. Eur. J., 19 (2013), pp. 1858-1871

[36] J.M. Stevens, D.W.C. MacMillan J. Am. Chem. Soc., 135 (2013), pp. 11756-11759 
[37] D.J. Berrisford, C. Bolm, K.B. Sharpless Angew. Chem. Int. Ed., 34 (1995), pp. 1059-1070

[38] C.E. Meyet, C.J. Pierce, C.H. Larsen Org. Lett., 14 (2012), pp. 964-967

[39] X. Tang, J. Kuang, S. Ma Chem. Commun., 49 (2013) 8976-3

[40] A. Becke Phys. Rev. A Gen. Phys., 38 (1988), pp. 3098-3100

[41] P.J. Hay, W.R. Wadt J. Chem. Phys., 82 (1985), pp. 270-283

[42] R.A. Kendall, T.H. Dunning Jr., R.J. Harrison J. Chem. Phys., 96 (1992), pp. 6796-6806

[43] M.G. Evans, M. Polanyi Trans. Faraday Soc., 31 (1935), pp. 875-894

[44] I. Thomsen, U. Pedersen, P.B. Rasmussen, B. Yde, T.P.Andersen, S.O. Lawesson Chem. Lett. (1983), pp. 809810

[45] G. Stork, A. Brizzolara, H. Landesman, J. Szmuszkovicz, R.Terrell J. Am. Chem. Soc., 85 (1963), pp. 207-222

[46] D. Sánchez, D. Bastida, J. Burés, C. Isart, O. Pineda, J. Vilarrasa Org. Lett., 14 (2012), pp. 536-539

[47] B.A. Trofimov, E.Y. Schmidt, N.V. Zorina, E.V. Ivanova, I.A.Ushakov J. Org. Chem., 77 (2012), pp. 6880-6886

[48] M.D. Hanwell, D.E. Curtis, D.C. Lonie, T. Vandermeersch, E.Zurek, G.R. Hutchison J. Cheminf., 4 (2012), p. 17 